\title{
Abrupt climate changes of the last deglaciation detected in a Western Mediterranean forest record
}

\author{
W. J. Fletcher ${ }^{1,2}$, M. F. Sanchez Goñi ${ }^{1}$, O. Peyron ${ }^{3}$, and I. Dormoy ${ }^{3}$ \\ ${ }^{1}$ Ecole Pratique des Hautes Etudes, UMR 5805 CNRS EPOC, Université Bordeaux 1, Avenue des Facultés, 33405 Talence \\ cedex, France \\ ${ }^{2}$ Institute of Geosciences, Goethe-Universität, Frankfurt am Main 60438, Germany \\ ${ }^{3}$ CNRS UMR 6249 Laboratoire Chrono-Environnement, Université de Franche-Comté, 16 route de Gray, 25030 \\ Besançon, France
}

Received: 27 November 2008 - Published in Clim. Past Discuss.: 20 January 2009

Revised: 12 March 2010 - Accepted: 24 March 2010 - Published: 14 April 2010

\begin{abstract}
Abrupt changes in Western Mediterranean climate during the last deglaciation (20 to 6 cal ka BP) are detected in marine core MD95-2043 (Alboran Sea) through the investigation of high-resolution pollen data and pollenbased climate reconstructions by the modern analogue technique (MAT) for annual precipitation $\left(P_{\mathrm{ann}}\right)$ and mean temperatures of the coldest and warmest months (MTCO and MTWA). Changes in temperate Mediterranean forest development and composition and MAT reconstructions indicate major climatic shifts with parallel temperature and precipitation changes at the onsets of Heinrich stadial 1 (equivalent to the Oldest Dryas), the Bölling-Allerød (BA), and the Younger Dryas (YD). Multi-centennial-scale oscillations in forest development occurred throughout the BA, YD, and early Holocene. Shifts in vegetation composition and $P_{\text {ann }}$ reconstructions indicate that forest declines occurred during dry, and generally cool, episodes centred at 14.0, 13.3, $12.9,11.8,10.7,10.1,9.2,8.3$ and $7.4 \mathrm{cal} \mathrm{kaBP}$. The forest record also suggests multiple, low-amplitude Preboreal (PB) climate oscillations, and a marked increase in moisture availability for forest development at the end of the PB at $10.6 \mathrm{cal} \mathrm{ka} \mathrm{BP.} \mathrm{Dry} \mathrm{atmospheric} \mathrm{conditions} \mathrm{in} \mathrm{the} \mathrm{West-}$ ern Mediterranean occurred in phase with Lateglacial events of high-latitude cooling including GI-1d (Older Dryas), GI1b (Intra-Allerød Cold Period) and GS-1 (YD), and during Holocene events associated with high-latitude cooling, meltwater pulses and N. Atlantic ice-rafting. A possible climatic mechanism for the recurrence of dry intervals and an opposed regional precipitation pattern with respect to Westerncentral Europe relates to the dynamics of the westerlies and the prevalence of atmospheric blocking highs. Comparison
\end{abstract}

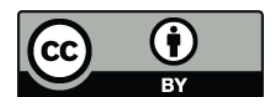

Correspondence to: W. J. Fletcher (w.fletcher@em.uni-frankfurt.de) of radiocarbon and ice-core ages for well-defined climatic transitions in the forest record suggests possible enhancement of marine reservoir ages in the Alboran Sea by $\sim 200$ years (surface water age $\sim 600$ years) during the Lateglacial.

\section{Introduction}

Numerous palaeoclimate records from Greenland ice cores, North Atlantic marine sequences and Northern European terrestrial sequences indicate that the last glacial-interglacial transition was punctuated in the North Atlantic region by abrupt (millennial- and centennial-scale) climate changes (e.g. NGRIP members, 2004; Björck et al., 1996; Dansgaard et al., 1993; Lehman and Keigwin, 1992; Bard et al., 1987). While questions remain about the ultimate role of internal climate variability, solar activity, volcanism and other forcings in the origin of these climatic oscillations, several lines of evidence including geological and modelling studies point to disruption of the oceanic thermohaline circulation (THC) by punctuated meltwater discharge as a likely mechanism for abrupt cooling of the North Atlantic region (e.g. Fleitmann et al., 2008; Flesche Kleiven et al., 2008; Renssen et al., 2007; Donnelly et al., 2005; Nesje et al., 2004; Teller et al., 2002; Clark et al., 2001).

In order to improve our understanding of the wider impacts of perturbation of the North Atlantic climate and the mechanisms underlying the transmission of climatic changes, highresolution palaeoclimate records are required from beyond the North Atlantic region. In this respect, the Mediterranean is a key region, being characterised by close atmospheric and oceanic linkages to the North Atlantic region but also by a distinct climatic regime and teleconnections to distant climate patterns including the African and Asian monsoons

Published by Copernicus Publications on behalf of the European Geosciences Union. 
(Lionello et al., 2006). Variability of the Western Mediterranean climate on millennial and shorter timescales since the end of the last glacial period remains poorly understood, as relatively few continuous palaeoclimate records are currently available with sufficient resolution and/or chronological control to permit the identification of discrete sub-millennial events. As such, outstanding questions remain regarding the timing, nature and mechanisms of abrupt climate changes in the Western Mediterranean region.

The preservation of terrestrial pollen and spores in long, continuous, and high-sedimentation rate marine cores of the Alboran Sea therefore provides an important line of information regarding vegetation and climate changes during the deglaciation associated with events of meltwater discharges and perturbation of the North Atlantic circulation (Combourieu Nebout et al., 2009, 2002; Fletcher and Sanchez Goñi, 2008). In this study we present evidence for multicentennial-scale fluctuations in temperate forest development and reconstructed climatic parameters (annual precipitation, winter and summer mean temperatures) during the last deglaciation period, i.e. 20 to 6 thousand calendar years before present (cal ka BP), from a marine sediment core from the Western Mediterranean basin.

\section{Study region}

The Alboran Sea is the westernmost basin of the Mediterranean Sea, located between SE Iberia and North Africa (Fig. 1). The lands bordering the Alboran Sea are dominated by the mountains of the Baetic-Rifan zone, reaching over $2400 \mathrm{~m}$ in the Rif (Morocco) and $3400 \mathrm{~m}$ in the Sierra Nevada (Spain). The regional climate is Mediterranean with hot, dry summers governed by the strength of the Azores anticyclone and mild, humid winters influenced by mid-latitude atmospheric circulation patterns and the latitudinal position of North Atlantic storm tracks (Lionello et al., 2006). Altitudinal contrasts yield a wide range of regional thermal conditions, with mean temperature of the warmest month (MTWA) between $20^{\circ} \mathrm{C}$ (high altitudes) and $25^{\circ} \mathrm{C}$ (low altitudes), and mean temperature of the coldest month (MTCO) between $2{ }^{\circ} \mathrm{C}$ and $12{ }^{\circ} \mathrm{C}$ (Arévalo Barroso, 1992). Regional precipitation patterns are strongly influenced by the westerly origin of Atlantic moisture and the orographic complexity of the neighbouring landmasses, with annual precipitation $\left(P_{\mathrm{ann}}\right)$ values ranging from $>1400 \mathrm{~mm} / \mathrm{yr}$ in the western BaeticRifan highlands to $<400 \mathrm{~mm} / \mathrm{yr}$ in the semi-desert lowlands of the eastern basin. Predominant wind directions are northwesterly during winter, with southerly and southwesterly winds occurring during summer associated with weakening of the westerlies.

In common with other areas of the Mediterranean basin, the distribution and composition of forest vegetation in the Alboran borderlands is influenced by thermal gradients related to altitude and by precipitation (Fig. 2) (Quezel, 2002;

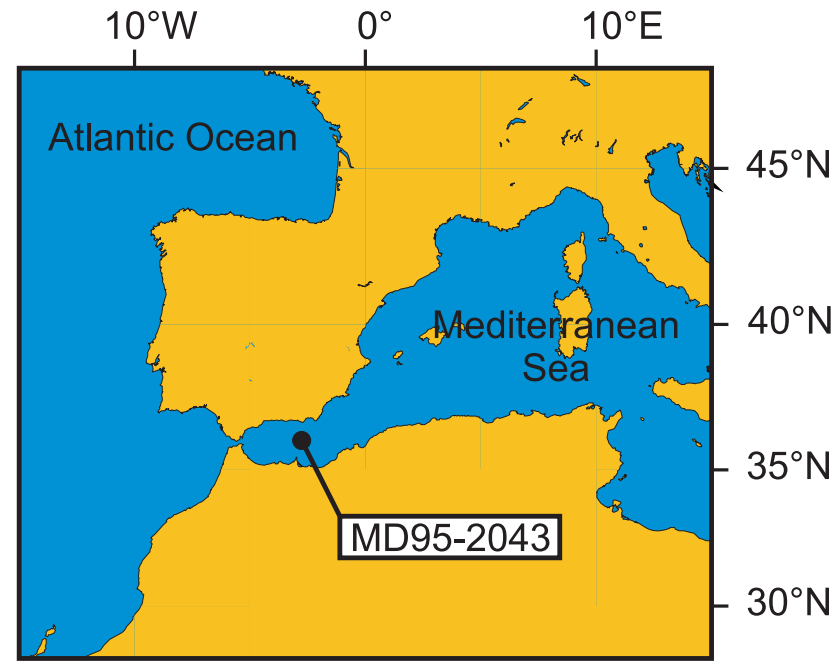

Fig. 1. Location of core MD95-2043 in the Western Mediterranean Sea.

Benabid, 2000; Peinado Lorca and Rivas-Martinez, 1987). Forest development is generally confined to sub-humid to humid areas corresponding approximately to $P_{\mathrm{ann}}>600 \mathrm{~mm} / \mathrm{yr}$, with drier areas dominated by forest-steppe and semi-desert steppe vegetation. Where conditions of sufficient moisture availability permit forest development, forest composition can be related to temperature gradients, with sclerophyllous shrublands and evergreen Quercus formations occurring at lower altitudes (thermo- and mesomediterranean stages, up to $\sim 1200 \mathrm{~m}$ ), mixed evergreen/deciduous and deciduous Quercus forest formations at mid-altitudes (supramediterranean stage, $\sim 1200-1800 \mathrm{~m}$ ), and montane Mediterranean coniferous vegetation (with Juniperus, Pinus, Abies and $\mathrm{Ce}$ drus) at higher altitudes (Quezel, 2002; Benabid, 2000; Peinado Lorca and Rivas-Martinez, 1987). Under the coldest conditions occurring near the mountain summits, forest vegetation gives way to xerophytic shrublands and pasturelands. The regional vegetation is nevertheless very strongly altered by anthropic pressure, such that the understanding of bioclimatic vegetation patterns is based heavily on vestigial forest fragments (Peinado Lorca and Rivas-Martinez, 1987).

\section{Data and methods}

\subsection{Chronology}

Core MD95-2043 $\left(36^{\circ} 9^{\prime} \mathrm{N}, 2^{\circ} 37^{\prime} \mathrm{W}, 1841 \mathrm{~m}\right.$ water depth) was recovered in the Alboran Sea (Western Mediterranean), and is characterised by continuous deposition of hemipelagic muds and high sedimentation rates throughout the deglaciation period (Cacho et al., 1999) (Fig. 3). The chronology for the deglaciation period is constrained by 13 AMS radiocarbon dates on monospecific foraminiferal samples, previously published in Cacho et al. (1999) (Table 1). The age-depth 
Table 1. AMS radiocarbon dates from core MD95-2043 (Cacho et al., 1999) used in the deglaciation age model.

\begin{tabular}{|c|c|c|c|c|c|}
\hline $\begin{array}{l}\text { Depth } \\
(\mathrm{cm})\end{array}$ & $\begin{array}{l}\text { Sample } \\
\text { type }\end{array}$ & $\begin{array}{l}{ }^{14} \mathrm{C} \text { age } \\
(\mathrm{yr} \mathrm{BP})\end{array}$ & Error & $\begin{array}{c}\text { Calibrated age, } 2 \sigma \\
(\text { yr cal BP })^{*}\end{array}$ & $\begin{array}{l}\text { Median probability } \\
\text { (yr cal BP })\end{array}$ \\
\hline 14 & G. bulloides & 1980 & \pm 60 & $1384-1690$ & 1538 \\
\hline 54 & G. bulloides & 3216 & \pm 37 & $2897-3162$ & 3029 \\
\hline 96 & G. bulloides & 4275 & \pm 41 & $4255-4510$ & 4391 \\
\hline 178 & G. bulloides & 5652 & \pm 42 & 5936-6172 & 6056 \\
\hline 238 & G. bulloides & 6870 & \pm 50 & $7276-7479$ & 7384 \\
\hline 298 & N. pachyderma & 8530 & \pm 47 & $9010-9301$ & 9165 \\
\hline 348 & G. bulloides & 9200 & \pm 60 & 9792-10176 & 10009 \\
\hline 418 & N. pachyderma & 9970 & \pm 50 & $10726-11115$ & 10944 \\
\hline 487 & N. pachyderma & 10560 & \pm 60 & $11406-12043$ & 11797 \\
\hline 512 & N. pachyderma & 10750 & \pm 60 & $11936-12571$ & 12172 \\
\hline 588 & N. pachyderma & 11590 & \pm 60 & 12949-13205 & 13088 \\
\hline 595 & N. pachyderma & 11880 & \pm 80 & $13172-13496$ & 13327 \\
\hline 682 & G. bulloides & 12790 & \pm 90 & $14068-14873$ & 14412 \\
\hline 708 & G. bulloides & 13100 & \pm 90 & $14493-15318$ & 14970 \\
\hline 758 & N. pachyderma & 14350 & \pm 110 & $16174-17049$ & 16618 \\
\hline 802 & N. pachyderma & 15440 & \pm 90 & $18041-18637$ & 18334 \\
\hline 858 & N. pachyderma & 18260 & \pm 120 & 20649-21517 & 21094 \\
\hline
\end{tabular}

*Converted to calendar ages using the Marine04 calibration curve (Hughen et al., 2004) implemented in CALIB (Stuiver and Reimer, 1993; version 5.02).

Table 2. Anomalies in temperate Mediterranean forest (TMF) values and MAT reconstructions associated with MD95-2043 forest decline events, calculated on the basis of changes in the smoothed (3-point moving average) values relative to the preceding interval.

\begin{tabular}{lrrrr}
\hline $\begin{array}{l}\text { Forest event } \\
\text { ccentral age estimate } \pm 2 \sigma, \mathrm{ka} \mathrm{cal} \mathrm{BP})\end{array}$ & $\begin{array}{r}\Delta \mathrm{TMF} \\
(\%)\end{array}$ & $\begin{array}{r}\Delta P_{\mathrm{ann}} \\
(\mathrm{mm})\end{array}$ & $\begin{array}{r}\Delta \mathrm{MTCO} \\
\left({ }^{\circ} \mathrm{C}\right)\end{array}$ & $\begin{array}{r}\Delta \mathrm{MTWA} \\
\left({ }^{\circ} \mathrm{C}\right)\end{array}$ \\
\hline Decline $(7.4 \pm 0.1)$ & -15 & -120 & -1 & -1 \\
Decline $(8.3 \pm 0.1)$ & -8 & -20 & -2 & $*$ \\
Decline $(9.2 \pm 0.1)$ & -9 & -100 & +2 & -1 \\
Decline $(10.1 \pm 0.2)$ & -6 & -45 & $+<1$ & $*$ \\
Decline $(10.7 \pm 0.2)$ & -7 & -70 & +2 & -1 \\
Decline $(11.8 \pm 0.3)$ & -11 & -10 & +1 & $*$ \\
Decline $(12.9 \pm 0.2)($ Onset $Y D)$ & -19 & -240 & -5 & -3 \\
Decline $(13.3 \pm 0.2)$ & -13 & -85 & +2 & $-<1$ \\
Decline $(14.0 \pm 0.3)$ & -14 & -70 & $*$ & $-<1$ \\
Decline $($ Onset H1) & -4 & -170 & -10 & -3 \\
\hline
\end{tabular}

*no anomaly clearly associated with this event.

model used for the calculation of sample ages is based on linear interpolation between the median ages of the probability distribution of the calibrated dates (Table 1, Fig. 3). Uncertainties for interpolated sample ages are derived from the envelope of $2 \sigma$ probability distributions (illustrated in Fig. 3). This method yields uncertainties of between \pm 0.1 and $\pm 0.3 \mathrm{ka}$ for the ages of multi-centennial scale events detected in the pollen record (Table 2). Due to long-term changes in sedimentation rate (Fig. 3) sampling for pollen analysis at $5 \mathrm{~cm}$ intervals provides an average temporal resolution of 110 years for the period 6 to $20 \mathrm{cal} \mathrm{kaBP}$, and
70 years for the period 9 to 15 cal ka BP. For this study, radiocarbon dates were calibrated using the Marine04 calibration curve (Hughen et al., 2004), which incorporates a standard marine reservoir correction of $\sim 400$ years (Table 1 ). Variation in regional reservoir ages may have occurred during the last deglaciation (Siani et al., 2001), and possible implications for reservoir ages at the core location are considered further in Sect. 5.3 in light of the identification of specific climatic transitions in the pollen record. 


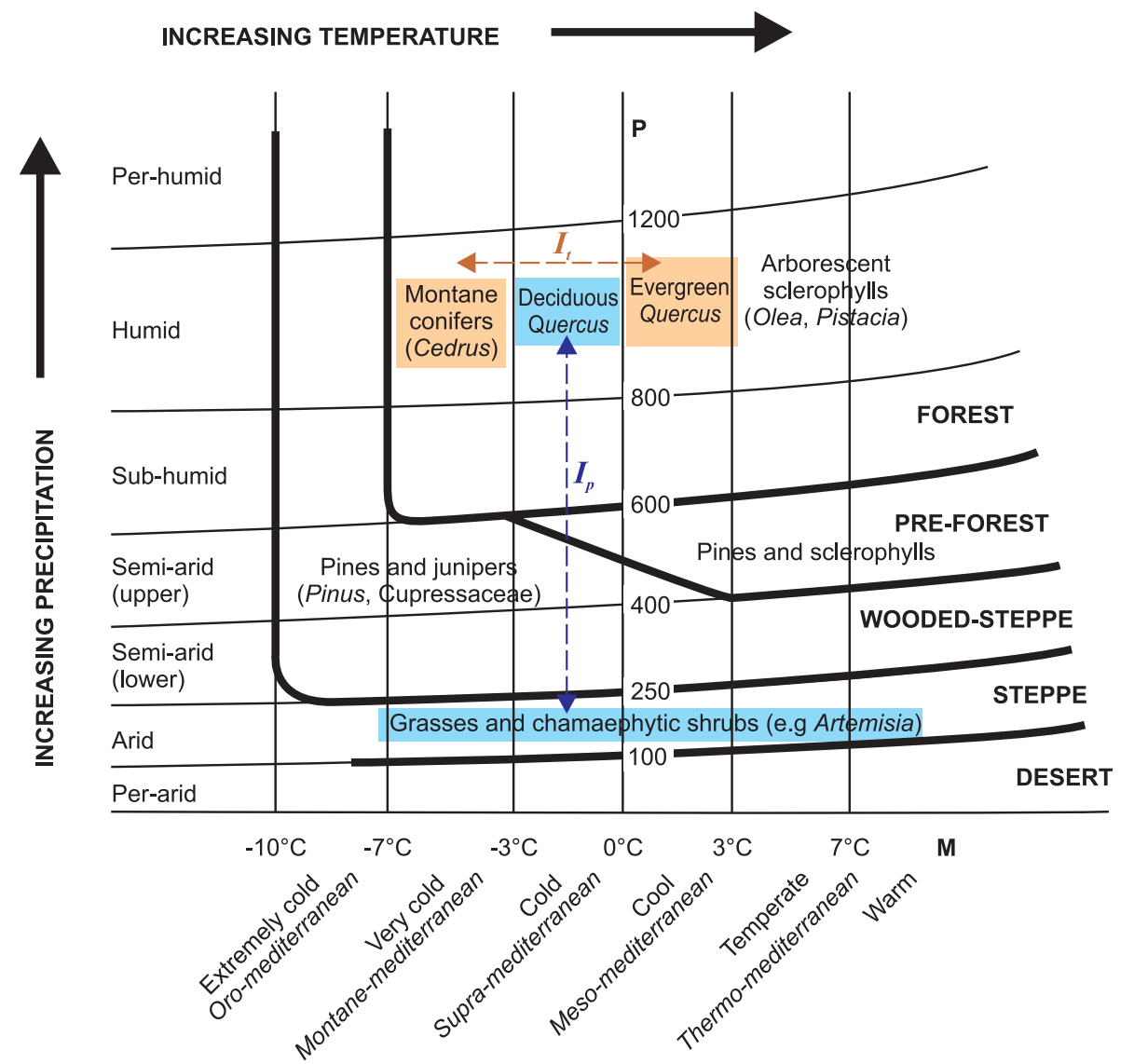

Fig. 2. Schematic diagram showing the distribution of vegetation types in the Alboran borderlands with respect to climatic gradients $P$ (annual precipitation) and M (average maximum temperature of the coldest month of the year) adapted from Quezel (2002). The distribution in climatic space of select vegetation types which are well-represented in the pollen record (deciduous Quercus, evergreen Quercus, montane conifers and semi-desert plants) provides the conceptual basis for the construction of the pollen indices $I_{t}$ and $I_{p}$.

\subsection{Pollen data}

Pollen data for the deglaciation section of the core (Fig. 4) was obtained employing standard methods of pollen extraction, identification and counts reported in Fletcher and Sanchez Goñi (2008). All pollen data for marine core MD952043 are permanently archived and accessible at Pangaea. In this paper, we focus on the pollen percentage record of temperate Mediterranean forest (TMF), a summary category which groups all pollen types typical of the thermomediterranean to supramediterranean altitudinal forests, namely Acer, Alnus, Betula, Corylus, Fraxinus excelsior type, Populus, Taxus, Ulmus, Quercus deciduous type, Quercus evergreen type, Quercus suber type, Cistus, Coriaria myrtifolia, Olea, Phillyrea, and Pistacia. Of these constituent taxa, oaks (Quercus spp.) are the dominant component, representing $\sim 90 \%$ of the TMF pollen. Olea and Pistacia are frequently present at low percentages $(<10 \%)$, and other TMF components are characterised by rare occurrences in the record. The TMF category is similar to the commonly used arboreal pollen (AP) category, but excludes the montane (cold-tolerant) conifer Cedrus and coldand arid-tolerant conifers in the family Cupressaceae. (The montane taxon Abies, which occurs only rarely in pollen record, is also excluded). As such, increases in TMF percentage values are considered to reflect the regional development of warmth- and moisture-demanding forest vegetation in response to favourable (warm and humid) climatic conditions. Other major components of the pollen spectra include heliophytic herbaceous and shrubby taxa of predominantly open ground habitats (e.g. Poaceae, various Asteraceae types), and xerophytic shrubs characteristic of semidesert habitats (Artemisia, Chenopodiaceae, Ephedra distachya type) (Fig. 4). A small hygrophytic component (notably Cyperaceae) reflecting wetland habitats is present. The curve for this component shows long-term parallels with the TMF curve, highlighting the dependence of both forest and wetland vegetation on moisture availability in this region. 


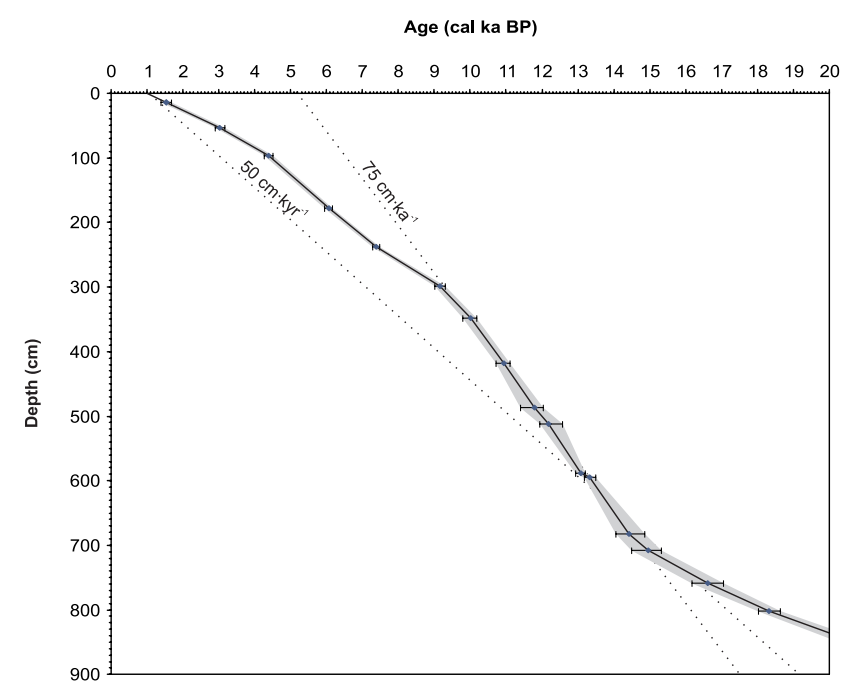

Fig. 3. Age-depth profile for core MD95-2043 (last $20 \mathrm{ka}$ ) based on calibrated AMS radiocarbon data from Cacho et al. (1999) shown in Table 1 , showing the central age estimate and $2 \sigma$ uncertainty intervals. The shaded band shows the $2 \sigma$ uncertainty envelope.

Informed by the present-day distribution of regional vegetation types along temperature and precipitation gradients (Fig. 2), two pollen indices based on the ratios of select pollen taxa are proposed with the aim of examining temperature and precipitation signals in the pollen record. An advantage of these indices is that, unlike pollen percentages, each is effectively independent of fluctuations in other taxa in the pollen spectrum. The proposed indices are based on well-represented pollen taxa with unambiguous pollen morphologies. The first index, $I_{t}$ (Fig. 4), is defined as $Q \mathrm{e} /(C C$ $+Q \mathrm{e}$ ), where $Q \mathrm{e}$ is the number of pollen grains of Quercus evergreen type and $C C$ is the combined number of pollen grains of Cedrus and Cupressaceae. As forest composition changes strongly reflect temperature gradients related to altitude (Fig. 2), $I_{t}$ should primarily reflect changes in regional temperature, with low values reflecting the increase of montane conifer forest under cooler conditions, and high values reflecting the increase of mesomediterranean forest with evergreen oaks under warmer conditions. Although Cupressaceae pollen may include both montane (cold-tolerant) and forest-steppe (arid-tolerant) species in the pollen type, the percentage curves of Cupressaceae and Cedrus display similar behavior across the deglaciation interval, suggesting parallel response to a common forcing. In any case, experimentation reveals trends and patterns in the resulting index $I_{t}$ to be robust whether Cupressaceae is included, as shown here, or not.

The second index, $I_{p}$, is defined as $Q \mathrm{~d} /(\mathrm{SD}+Q \mathrm{~d})$, where $Q \mathrm{~d}$ is the number of pollen grains of Quercus deciduous type and SD is the number of pollen grains of semi-desert taxa (Artemisia, Chenopodiaceae and Ephedra distachya type). As the regional development of semi-desert vegetation oc- curs under arid conditions regardless of altitude and temperature (Fig. 2), $I_{p}$ should primarily reflect changes in regional moisture availability, with low values reflecting the increase of semi-desert vegetation under drier conditions, and high values reflecting the increase of moisture-demanding forest.

\subsection{Quantitative climate reconstruction}

A climate reconstruction based on the full pollen data-set was performed using the modern analogue technique (MAT) (Guiot, 1990; Peyron et al., 1998). In this technique, fossil pollen assemblages are compared with a modern pollen dataset, and the closest modern analogues are selected on the basis of a dissimilarity coefficient (chord distance) (Guiot, 1990). Climatic values for selected parameters (in this case, MTCO, MTWA and $\left.P_{\mathrm{ann}}\right)$ are then calculated for each fossil assemblage on the basis of a weighted average (inversely weighted with respect to the dissimilarity coefficient) of the modern values of the climatic parameters at the geographic locations of the modern analogues. The MAT reconstructions were based on the 10 closest analogues from an expanded database of modern pollen spectra $(n=3530)$ from Europe, Asia and Northern Africa (described in Bordon et al., 2009). The database includes, importantly, more extensive coverage of the Mediterranean region than an earlier database $(n=1487)$ used for previously published reconstructions for Marine Isotope Stage 3 on core MD95-2043 (Sanchez Goñi et al., 2002). Due to the overrepresentation of Pinus pollen in marine assemblages, Pinus is excluded from both the fossil and modern database samples, following the practise employed in a number of recent reconstructions performed on marine pollen samples (Combourieu-Nebout et al., 2009; Dormoy et al., 2009; Kotthoff et al., 2008; Desprat et al., 2005; Sanchez Goñi et al., 2002).

The reliability of MAT reconstructions based on marine pollen samples has been recently evaluated using 22 marine core-top samples from the Mediterranean region (Combourieu-Nebout et al., 2009). The results suggest a reasonable consistency between observed and reconstructed climate, but also highlight certain challenges in the reconstruction of Mediterranean climates arising from the integration of a wide regional signal in marine pollen assemblages (Combourieu-Nebout et al., 2009). Therefore, although the MAT is employed here in an initial effort to provide quantitative estimates for climate changes associated with abrupt changes in the pollen record, it is evident that both future refinement of MAT through the development of more extensive databases of marine core-top pollen assemblages and the application of other techniques of quantitative climate reconstruction may improve these estimates in the future. 


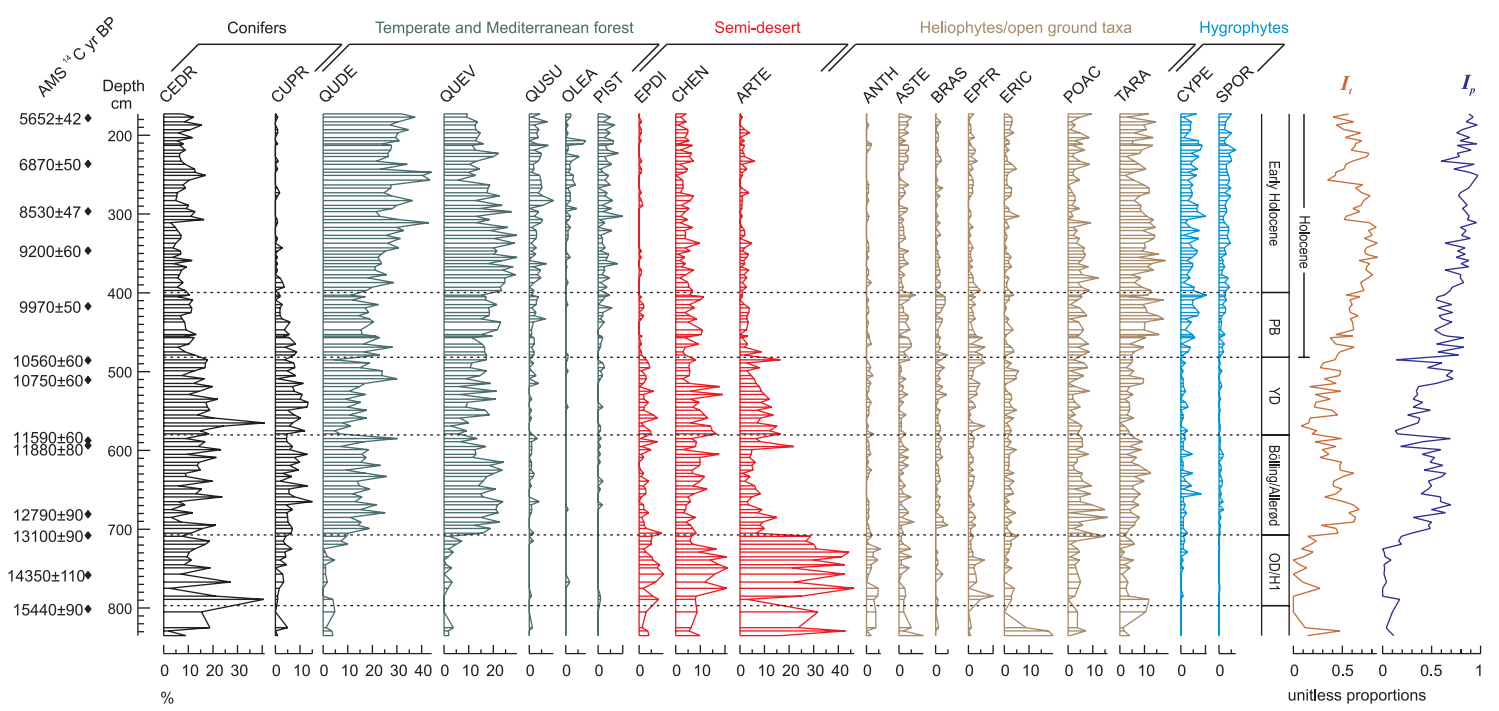

Fig. 4. Pollen percentage data plotted against depth from core MD95-2043 for major taxa Cedrus (CEDR), Cupressaceae (CUPR), Quercus deciduous type (QUDE), Quercus evergreen type (QUEV), Olea (OLEA), Pistacia (PIST), Ephedra distachya type (EPDI), Chenopodiaceae (CHEN), Artemisia (ARTE), Anthemis type (ANTH), Aster type (ASTE), Brassicaceae (BRAS), Ephedra fragilis type (EPFR), Ericaceae (ERIC), Poaceae (POAC), Taraxacum (TARA), Cyperaceae (CYPE) and fern spores (SPOR). Pollen data available online at doi:10.1594/PANGAEA.711649. Also shown are the pollen-based indices $I_{t}$ and $I_{p} . I_{t}$ describes the ratio of evergreen $Q u e r c u s$ to conifers (Cedrus and Cupressaceae); $I_{p}$ describes the ratio of deciduous Quercus to semi-desert taxa. In light of the modern distribution of these taxa with respect to regional climatic gradients (Fig. 2), $I_{t}$ and $I_{p}$ should primarily reflect temperature and precipitation variability, respectively.

\section{Results}

\subsection{Variability in temperate Mediterranean forest}

The temperate Mediterranean forest (TMF) pollen curve (Fig. 5) reveals a long-term recovery of forest populations across the last glacial-interglacial transition, with minimum values $(<10 \%)$ during the $\mathrm{H} 1$ interval (as defined on the basis of marine climatic tracers in the same core (Cacho et al., 2006, 1999; Fletcher and Sanchez Goñi, 2008)), intermediate values $(15-50 \%)$ during the Lateglacial and Preboreal (PB), and high values (>50\%) after $10.6 \mathrm{cal} \mathrm{ka} \mathrm{BP.} \mathrm{Follow-}$ ing the expansion of forest populations at the end of $\mathrm{H} 1$, discrete intervals of reduced forest development are detected (in all cases by the values of at least two samples) throughout the Lateglacial and early Holocene, centred on 14.0, 13.3, 12.9, 11.8, 10.7, 10.1, 9.2, 8.3, and 7.4 cal ka BP (Fig. 5, Table 2). Decreased abundance of TMF taxa (corresponding to increases in semi-desert, open ground and coniferous vegetation) suggests regional forest declines in response to unfavourable (dry and/or cold) atmospheric conditions. In general, the results are in close agreement with trends and patterns of forest development detected in the pollen record of Alboran marine core ODP site 976 (Combourieu Nebout et al., 2009), supporting the regional validity of the findings.

Throughout the H1, BA, YD and PB intervals, remarkable similarities in the pollen indices $I_{p}$ and $I_{t}$ (Fig. 5) suggest predominantly parallel changes in precipitation and tem- perature with the consistent association of colder conditions (lower values of $I_{t}$ ) with reduced moisture availability (lower values of $I_{p}$ ). Centennial-scale intervals of TMF decline during the deglaciation centred at 14.0, 13.3, 12.9, 12.4, 11.8 and $10.7 \mathrm{cal}$ ka BP correspond with shifts towards a more montane forest composition and the expansion of semi-arid vegetation as detected in lower values of both $I_{t}$ and $I_{p}$, respectively. These intervals thus appear to indicate episodes of combined atmospheric cooling and drying.

After the PB, the parallels between TMF, $I_{t}$ and $I_{p}$ values are less evident, with notably divergent changes in $I_{t}$ and $I_{p}$. This change in dynamic results from the fact that TMF declines centred at 10.1, 9.2, 8.3, and $7.4 \mathrm{cal} \mathrm{kaBP}$ primarily reflect increases in open ground taxa (which are not reflected in $I_{t}$ and $I_{p}$ values). TMF declines at 9.2 and $8.3 \mathrm{cal} \mathrm{kaBP}$ occur within an interval of lower values of $I_{p}$, and the decline at $7.4 \mathrm{cal} \mathrm{ka} \mathrm{BP}$ similarly corresponds to a decrease in $I_{p}$ suggesting that the expansion of open ground habitats at the expense of forest vegetation was associated with reduced moisture availability during these events. In common with earlier deglacial events, the TMF decline at $9.2 \mathrm{cal} \mathrm{kaBP}$ is associated with a reduction in $I_{t}$, suggesting that atmospheric cooling is implicated in vegetation changes during this forest decline event. In contrast, TMF declines at 8.3 and $7.4 \mathrm{cal} \mathrm{kaBP}$ are not clearly associated with reduced $I_{t}$ values, and quite marked changes in $I_{t}$ after 9.2 cal ka BP moreover occur in virtual anti-phase with respect to $I_{p}$. These observations suggest that early Holocene 


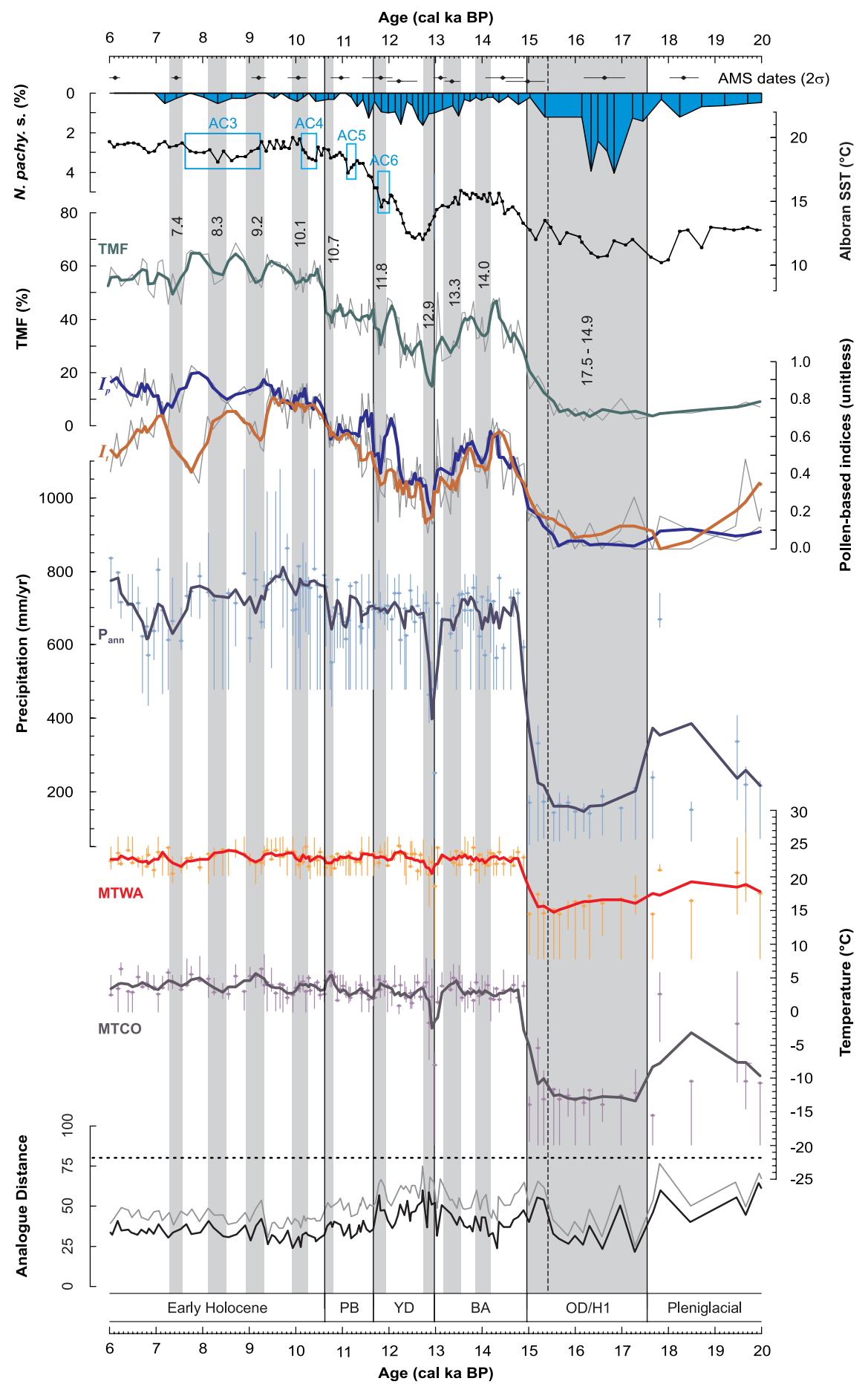

Fig. 5. Marine and terrestrial climatic tracers and pollen-based MAT climate reconstructions for the last deglaciation in core MD95-2043, plotted against age. Cold-water foraminifer N. pachyderma s. abundances and alkenone SST reconstruction from Cacho et al. (1999) shown with the positions of Alboran Sea cooling events (AC3-6), as defined in Cacho et al. (2001). Pollen percentages for temperate Mediterranean forest (TMF) taxa and curves for $I_{t}$ and $I_{p}$ are shown (raw values and 3-point moving average). Grey bars indicate multi-centennial-scale TMF declines, labelled with the central age estimate of the interval (in cal ka BP). Dashed vertical line marks the earliest signs of forest expansion during the glacial-interglacial transition (see Sect. 5.1.2). MAT reconstructions are shown for annual precipitation ( $\left.\mathrm{P}_{\mathrm{ann}}\right)$, mean temperature of the coldest month (MTCO), and mean temperature of the warmest month (MTWA). MAT reconstructions show the central estimate for each sample with error range, and a 3-point moving average curve. The analogue distances (dissimilarity coefficient) for the nearest (black curve) and farthest (grey curve) of the ten best modern analogues are shown; the dotted line indicates the Monte-Carlo cut-off value for acceptable analogues. 
TMF declines consistently reflect dry atmospheric conditions in the region, but that precipitation changes were not consistently in phase with temperature changes during this interval.

\subsection{Comparison with Alboran SSTs}

Comparison of the TMF and alkenone SST records from core MD95-2043 (Fig. 5) reveals that variability on long-term to millennial timescales during the deglaciation is in phase between the two records. Both trace a Lateglacial interstadialstadial oscillation, and show a progression towards maximum values during the early Holocene around $9.5 \mathrm{cal} \mathrm{ka} \mathrm{BP}$. On shorter (multi-centennial) timescales, however, variability in the two records is not always in phase. We note, for example, that marked oscillations in TMF within the BA or the abrupt increase in TMF at $10.6 \mathrm{cal}$ ka BP do not have counterparts in the SST record. Similarly, the Alboran cooling (AC) events defined on the basis of SST anomalies of around $1.5^{\circ} \mathrm{C}$ (Cacho et al., 2001) do not consistently correspond to changes in the TMF record (Fig. 5). While AC6 represents a cold reversal near the end of the YD interval that is clearly marked in both records, AC5 does not clearly correspond to changes in TMF (although this cooling appears part of a complex pattern of low-amplitude climatic variability during the $\mathrm{PB}$, discussed below). AC4 may be associated with a TMF decline centred at $10.1 \mathrm{cal} \mathrm{kaBP}$, although the structure of the event is different, with abrupt SST cooling contrasting with a more gradual forest decline. Finally, AC3 represents a relatively long interval during which two distinct forest declines are detected (centred at 9.2 and $8.3 \mathrm{cal} \mathrm{kaBP}$, respectively).

The differences evident in this direct comparison of terrestrial and marine signals in the same core (i.e. without chronological uncertainties) suggests either (i) an inconsistent coupling of atmospheric conditions and Western Mediterranean SSTs during multi-centennial scale climate events, and/or (ii) different proxy sensitivities to specific climatic parameters and/or seasonal influences. The differences may relate in part to the sensitivity of the regional forest vegetation to perturbation of the winter (humid) season climate, as detected over recent decades (Gouveia et al., 2008), while a summer signal may be more evident in the SST record due to the fact that alkenones are produced during the spring (bloom) season. In the case of TMF decline at $8.3 \mathrm{cal} \mathrm{kaBP}$, which occurs in the context of the longer AC3 SST cooling event, this contrast in seasonal significance is coherent with the previously suggested pattern for the $8.2 \mathrm{ka}$ event of a sharp cooling evident in winter-dominated proxies within a broad anomaly in summer-dominated proxies (Rohling and Pälike, 2005).

\subsection{MAT precipitation and temperature estimates}

The results of the MAT climate reconstruction are shown in Fig. 5. As marine pollen assemblages reflect a wide, regional pollen source area (Beaudouin et al., 2007; Naughton et al.,
2007; Mudie et al., 2002; Heusser and Balsam, 1977), the quantitative estimates based on the MAT are not considered precise values for a particular location, but rather an integrated estimate of a regional signal for the Alboran basin of the Western Mediterranean. For this reason, anomalies in the MAT reconstructions (Table 2) may be more informative than the absolute values for any given sample.

Three deglacial events (the onsets of Heinrich stadial 1 (H1), the BA and the YD) are marked by outstanding anomalies in all three parameters, with cooling (summer and winter) in parallel with drying (onsets H1, YD), or warming (summer and winter) with increased precipitation (onset BA). The remaining multi-centennial-scale forest declines are consistently associated with reduced precipitation estimates (Table 2, Fig. 5) with an average $P_{\text {ann }}$ anomaly of $-65 \mathrm{~mm} / \mathrm{yr}$. An increase in $P_{\mathrm{ann}}$ of $\sim 100 \mathrm{~mm} / \mathrm{yr}$ is also estimated at the end of the PB at $10.6 \mathrm{cal} \mathrm{kaBP}$. The MAT technique provides an estimate of the seasonal distribution of precipitation (not shown). $P_{\text {ann }}$ anomalies associated with forest decline events reflect decreases in reconstructed autumn to spring precipitation, and do not reflect changes in summer precipitation, supporting the view that forest declines reflect consistent perturbation of the winter (autumn to spring) climate. In contrast with $P_{\text {ann }}$, consistent relationships between episodes of forest decline and MTCO and MTWA anomalies are not detected, with different events either varying in seasonal temperature signature or showing no clear anomaly in association with the event. The long-term increase in temperature from the YD to the early Holocene suggested by increasing $I_{t}$ is also not replicated in the MAT reconstruction.

The sensitivity of the MAT reconstructions (in particular for temperature) to changes in the deglaciation pollen record should be assessed in light of the geographical location of the analogues and the analogue distances. Modern analogues for pollen spectra from the last glacial, H1 and the YD onset are located in Tibet and Kazakhstan, while modern analogues for the Holocene, YD (excluding the onset) and BA pollen spectra are located predominantly in Spain, Morocco, Syria and Turkey. This switching in geographical location of the analogues from Central Asia to the Mediterranean basin (and vice versa) occurs when arboreal pollen in the fossil samples exceeds (declines below) 20\% and semi-desert taxa declines below (exceeds) $40 \%$. The crossing of these threshold values in the pollen record and accompanying jump in geographical location of the analogues at the onset of the BA and (in the opposite direction) at the onset of the YD may underline the much larger changes in climatic parameters reconstructed for these transitions compared with the remainder of the record.

Analogue distances (i.e. dissimilarity between the fossil and modern pollen spectra) are also much lower during $\mathrm{H} 1$ and the early Holocene than during either the BA, YD or PB interval (Fig. 5). This contrast suggests that while reasonable analogues are available for either semi-desert steppe (H1) or well-developed Mediterranean forest (early Holocene), good analogues may not be available for transitional wooded- 
steppe and open forest vegetation of the BA, YD and PB. This lack of analogues may result from non-analogue climatic conditions during this interval, or equally may be due to the present-day scarcity of comparable Mediterranean wooded-steppe vegetation due to the fragility of such landscapes with respect to anthropic pressure. In either case, the greater dissimilarity between fossil and modern spectra during the Lateglacial may partly underline the apparently low sensitivity of the temperature reconstructions to compositional changes in the fossil pollen spectra during this interval.

\section{Discussion}

\subsection{Abrupt climate changes}

\subsubsection{Heinrich stadial 1}

Temperate and Mediterranean forest populations were extremely reduced during H1 (17.5-14.9 cal ka BP), consistent with the pattern of severe forest declines detected for earlier Heinrich stadials (H5-H2) (Fletcher and Sanchez Goñi, 2008). The MAT estimates support inferences based on the indices $I_{t}$ and $I_{p}$ that $\mathrm{H} 1$ was associated with the coldest and driest atmospheric conditions of the deglaciation period in the Western Mediterranean, with negative anomalies in reconstructed climate parameters with respect to preceding Last Glacial Maximum conditions $\left(\Delta P_{\mathrm{ann}}=-170 \mathrm{~mm}\right.$, $\left.\triangle \mathrm{MTCO}=-10^{\circ} \mathrm{C}, \triangle \mathrm{MTWA}=-3^{\circ} \mathrm{C}\right)$. The very severe conditions detected during this interval are coeval with the virtual elimination of meridional overturning in the North Atlantic (McManus et al., 2004), suggesting that reduced northward transport of oceanic heat impacted strongly on warmth and evaporative moisture supply to the Western Mediterranean region. The findings reinforce those of other studies from the Iberian margin (Combourieu-Nebout et al., 2009, 1998; Naughton et al., 2007), namely that H1 is the equivalent of the Oldest Dryas, a cold interval at the end of the last glacial period characterised by marked aridity and the expansion of semi-desert environments in the Mediterranean region (e.g. Drescher-Schneider et al., 2007; Magri, 1999; Pérez-Obiol and Julià, 1994; Pons and Reille, 1988).

\subsubsection{Glacial-interglacial transition}

Rapid forest expansion in phase with SST warming marks the last glacial-interglacial transition (Fig. 5). This forest expansion is observed to have occurred in two stages, identified as an initial inter-sample increase in TMF values from 4 to $15 \%$ at $722 \mathrm{~cm}$ depth, and a second inter-sample increase from 14 to $30 \%$ at $707 \mathrm{~cm}$, corresponding to ages of 15.4 and $14.9 \mathrm{cal} \mathrm{kaBP}$, respectively ( $2 \sigma$ uncertainty $\sim \pm 0.4 \mathrm{ka}$ ). The detection of an interval of initial (relatively weak) forest recovery followed by a second (more substantial and sustained) forest increase reproduces the pattern of oak expansion detected at the Southern Iberian site of Padul (pollen zones P3i-P3j ) (Pons and Reille, 1988), confirming the regional validity of this pattern. MAT reconstructions indicate $P_{\mathrm{ann}}$, MTCO and MTWA within the range of glacial and $\mathrm{H} 1$ values for the interval following the first forest expansion, and large positive anomalies $\left(\Delta P_{\text {ann }}=+420 \mathrm{~mm}\right.$, $\triangle \mathrm{MTCO}=+17^{\circ} \mathrm{C}, \triangle \mathrm{MTWA}=+8^{\circ} \mathrm{C}$ ) for the second forest expansion (Fig. 4).

Within uncertainties in the radiocarbon age model, the initial (minor) forest expansion is synchronous with indications of moderate atmospheric changes prior to the abrupt onset of the Bölling (GI-1) in Greenland ice-core records at $14.7 \pm 0.01 \mathrm{ka}$ (Rasmussen et al., 2006). These indications include the increase in warmth and hydrological activity as detected in Northern Hemisphere speleothem records from Villars and Chauvet caves (Southern France), La Mine cave (Tunisia), and Hulu and Dongge caves (China) between 15.5 and $16 \mathrm{ka}$ (Genty et al., 2006; Dykoski et al., 2005; Wang et al., 2001), as well as a slight high-latitude warming trend seen in the Greenland ice-cores preceding GI-1 (NGRIP members, 2004; Grootes et al., 1993; Dansgaard et al., 1993). This interpretation is supported by indications in the marine climate proxies from core MD95-2043 (e.g. planktonic and benthic oxygen isotopes, $N$. pachyderma (s) abundances) of glacial marine conditions extending throughout the period of the initial forest expansion (Cacho et al., 2006, 1999). In this case, the second and larger forest expansion and reconstructed shift in precipitation and temperature may correspond with the abrupt onset of the Bölling as detected in Greenland ice-core records at $\sim 14.7 \mathrm{ka}$ (NGRIP members, 2004; Rasmussen et al., 2006).

\subsubsection{Bölling/Allerød}

Forest development during the BA suggests sustained wetter and warmer atmospheric conditions compared with the preceding H1 interval. These conditions were probably contingent upon the resumption of strong meridional overturning in the North Atlantic (McManus et al., 2004). Trends in $I_{t}$ and $I_{p}$ suggest that atmospheric warmth and moisture availability increased over the early part of the interstadial (GI1e, Bölling), in contrast to Greenland temperatures which peaked at the onset of GI-1and immediately began to decline (Jouzel et al., 2007; NGRIP members 2004). This contrast during the early part of the BA between high-latitude cooling and mid-latitude warming has been suggested to relate to increasing high-latitude sea-ice cover, weakening THC and southward migration of the polar front away from Greenland (Jouzel et al., 2007; von Grafenstein et al., 1999). This contrast has also been shown to be a recurrent feature of the intra-interstadial evolution of earlier Greenland Interstadials 8 and 12 (Sanchez Goñi et al., 2009).

From the end of the Bölling onwards, $I_{t}$ and $I_{p}$ values suggest a longer-term decline in temperatures and precipitation towards the YD onset, which in this case more closely resembles continued high-latitude cooling. This cooling 
trend is not evident in the SST record, which exhibits a plateau-like structure prior to marked cooling at the onset of the YD (Fig. 5), and also contrasts with stable or warming BA trends evident in several European palaeoclimate records (Genty et al., 2006; von Grafenstein et al., 1999) and in Greenland ice core proxies for mid-latitude source signals (Jouzel et al., 2007). These observations suggest that Western Mediterranean atmospheric conditions may have been more sensitive than local SSTs to remote shifts in the polar front implicated in the high-latitude cooling trend, and that a greater degree of spatial complexity in European BA climate trends exists than previously anticipated. However, the finding disagrees with a BA warming trend recently suggested on the basis of the nearby pollen record from ODP site 976 (Combourieu Nebout et al., 2009), and may therefore represent a highly localised phenomenon.

During the BA, two discrete multi-centennial-scale declines in temperate forest populations are detected, centred at 14.0 and $13.3 \mathrm{cal} \mathrm{ka} \mathrm{BP} \mathrm{(Fig.} \mathrm{5).} \mathrm{Modern} \mathrm{analogues} \mathrm{sug-}$ gest that vegetation changes during these declines were associated with $P_{\text {ann }}$ declines of around $70-85 \mathrm{~mm} / \mathrm{yr}$ (Table 2), and forest composition changes reflected in $I_{t}$ suggest that atmospheric drying was accompanied by cooler temperatures. These dry and cool events are in phase and, within age uncertainties, contemporary with high-latitude cooling events as detected in the Greenland ice-cores during GI1d (Older Dryas) and GI-1b (Intra-Allerød Cold Period), and in phase with central European cooling during the Aegelsee and Gerzensee Oscillations (Lotter et al., 1992). The MD952043 evidence for forest declines and cool, dry conditions confirms that these events were expressed not only in the Atlantic climate sector of the Iberian Peninsula (Muñoz Sobrino et al., 2007; van der Knaap and van Leeuwen, 1997) but also in the Mediterranean sector. The findings suggest an opposed palaeohydrological pattern with central-Western Europe, as GI-1d and GI-1b are characterised by higher lakelevels in the Swiss Plateau, Jura mountains and French PreAlps (Magny, 2001).

\subsubsection{Younger Dryas}

An abrupt and pronounced forest decline (identified as an inter-sample reduction of $\sim 35 \%$ in TMF values) marks the onset of the YD. This crash in temperate forest populations occurred within an age-model period of $\sim 70$ years and precedes the minimum in SSTs (Fig. 5) suggesting a rapid vegetation response to dry and cold atmospheric conditions in advance of maximum sea surface cooling. In timing and abrupt nature, the onset of the YD in the forest record is similar to that recorded in the speleothem records at Chauvet and La Mine caves (Genty et al., 2006), suggesting a common response to an abrupt change in atmospheric climatic conditions. Reductions of $\sim 240 \mathrm{~mm} / \mathrm{yr}$ in $P_{\mathrm{ann}}, 5^{\circ} \mathrm{C}$ in MTCO and $3{ }^{\circ} \mathrm{C}$ in MTWA are reconstructed for the onset of the YD. The magnitude of these anomalies, second only to the onset of $\mathrm{H1}$ in severity, matches well the relative decline in meridional overturning at this time (McManus et al., 2004), suggesting a similar, though weaker, impact of reduced oceanic heat transport on Western Mediterranean precipitation and temperatures to $\mathrm{H} 1$.

Following the initial forest decline, a general trend of forest recovery during the YD is observed which parallels the gradual reinvigoration of meridional overturning (McManus et al., 2004) and signals of climatic warming in the speleothem records (Genty et al., 2006). However, the TMF record for the YD also displays complex internal variability at multi-centennial timescales, with a marked intraYD interval of forest recovery between $12.2-11.9$ cal ka BP. This interval, corresponding to a positive $\Delta P_{\text {ann }}$ anomaly of $\sim 70 \mathrm{~mm} / \mathrm{yr}$, is in phase with a local peak in SSTs preceding the AC6 cooling reversal (Cacho et al., 2001, Fig. 5). The timing of the event is consistent with a short-lived warming over the European mainland detected in the Chauvet Cave and Ammersee $\delta^{18} \mathrm{O}$ records at 12.15 and $12.2 \mathrm{ka}$, respectively (Genty et al., 2006; von Grafenstein et al., 1999), and may be related to mid-YD warming events detected in a number of terrestrial lake records (Magny et al., 2006; Hammarlund et al., 1999) and in the Aegean marine pollen record SL 152 (Dormoy et al., 2009). This interval may reflect an episode of moderate reinvigoration of THC inside the YD interval related to changes in meltwater routing from the Canadian ice-sheets (Carlson et al, 2007). The MD952043 record indicates that this interval was expressed in the Western Mediterranean region in terms of increased moisture availability for forest development. A short-lived return to colder and drier conditions indicated by a TMF decline centred at $11.8 \mathrm{cal} \mathrm{kaBP}$ is evident at the end of the YD interval.

Precipitation patterns within the YD (GS-1) interval again appear opposed to patterns in mid-European lake-levels, where the early and late stages of the YD are marked by high lake-levels, with a middle phase of lake-level lowering (Magny, 2001; Magny et al., 2006). In contrast, the precipitation patterns are quite similar to inferred hydrological changes in the varved YD record at the more northerly site of Meerfelder Maar (Brauer et al., 1999) (Fig. 6). Accounting for differences in temporal resolution and an apparent age offset of $\sim 250$ years between the two site chronologies, the inferred precipitation index $I_{p}$ from MD95-2043 displays a remarkably similar structure to the varve thickness record, with drier conditions (low $I_{p}$ values) corresponding with thicker varves in the Meerfelder sequence. At Meerfelder Maar, thick varves deposited at the onset and during the early part of the YD reflect predominantly biogenic opal sediments with high Pediastrum content, considered an indication of high soil erosion and lake level lowering under dry conditions (Brauer et al., 1999). During the mid- to -late YD, a transition to thinner varves reflects a change to predominantly clastic deposition related to hydrological catchment changes under a likely increase in precipitation (Brauer et 
al., 1999). In light of the climatic interpretation of the varve thickness record proposed by Brauer et al. (1999), it appears that multi-centennial changes in precipitation were in phase between the Western Mediterranean and Northern Europe during the YD. Combined with the above mentioned evidence for opposite trends in mid-European lake levels, this comparison suggests that a continental tripartite pattern with a north to south division (dry-wet-dry) was evident during multi-centennial-scale episodes within the YD interval, similar to the situation proposed by Magny et al. (2007a, 2003) for the PB oscillation and $8.2 \mathrm{ka}$ event.

\subsubsection{Preboreal climate variability}

While the YD/Holocene boundary (11.7 cal ka BP) is marked by forest expansion and indications of increased warmth and moisture availability (increases in $I_{t}$ and $I_{p}$ ), the development of temperate Mediterranean forest appears limited during the PB period (11.7 to $10.6 \mathrm{cal} \mathrm{ka} \mathrm{BP}$ ). TMF values exhibit an overall plateau-like structure with low amplitude fluctuations culminating in a forest decline at the end of the PB centred at 10.7 cal ka BP. Vegetation composition changes reflected in $I_{t}$ and $I_{p}$ suggest that moisture variability may be primarily responsible for restricted TMF development during this interval. Temperatures appear to rise fairly steadily (increasing $I_{t}$ values) across the PB, with indications of minor cooling at 11.4 and $10.7 \mathrm{cal} \mathrm{kaBP}$. $I_{p}$ values, in contrast, suggest a short interval of higher moisture availability at the onset of the Holocene, followed by an abrupt shift towards drier conditions at $11.4 \mathrm{cal} \mathrm{ka} \mathrm{BP}$ and subsequent additional drying at 10.7 cal ka BP. Reconstructed $P_{\text {ann }}$ (reflecting compositional changes in the full pollen data-set) displays quite marked variability during the $\mathrm{PB}$, with local minima in precipitation reflecting anomalies of $-40 \mathrm{~mm} / \mathrm{yr}$ and $-70 \mathrm{~mm} / \mathrm{yr}$ at 11.4 and $10.7 \mathrm{cal} \mathrm{ka} \mathrm{BP}$, respectively. An additional $P_{\text {ann }}$ anomaly of $-80 \mathrm{~mm} / \mathrm{yr}$ at $11.1 \mathrm{cal} \mathrm{ka}$ BP may reflect an intervening dry episode between dry events at 11.4 and $10.7 \mathrm{cal} \mathrm{kaBP}$, perhaps in response to SST cooling during AC5 (Fig. 5); however this anomaly is associated with only a very minor $(<2 \%)$ negative shift in TMF values and is not detected in $I_{p}$ values.

The shift towards dry conditions during the early PB at 11.4 cal ka BP was coeval with a significant cooling anomaly (11.4 ka event) detected in $\delta^{18} \mathrm{O}$ and accumulation signals in multiple Greenland ice cores (Rasmussen et al., 2007). The evidence for drier conditions at this time in the MD95-2043 record is again consistent with contrasting precipitation patterns across Europe. Magny et al. (2007a), propose a tripartite latitudinal division (dry-wet-dry) in hydrological conditions for the PB oscillation, for which dryness in the southern sector is supported by our findings. In common with several central and northern European records which indicate a more complex pattern of multiple PB oscillations (Bohncke and Hoek, 2007; Magny et al., 2006; Björck and Wastegård, 1999; Whittington et al., 1996), our findings indicate that at least two, and possibly three, centennial-scale dry atmospheric episodes can be detected in the Western Mediterranean region.

\subsubsection{Early Holocene events}

An abrupt increase in forest populations is observed at 10.6 cal ka BP, suggesting a sustained climatic shift towards wetter conditions (high $I_{p}$ values and $P_{\text {ann }}$ estimations) in the context of increasing warmth (high $I_{t}$ values) (Fig. 5). While forest populations were strongly developed overall during the late phases of the last deglaciation, marked oscillations with forest declines centred at 10.1, 9.2, 8.3 and 7.4 cal ka BP indicate important sub-millennial variability in Western Mediterranean atmospheric conditions. Changes in the pollen-based indices $I_{t}$ and $I_{p}$ and the $P_{\text {ann }}$ reconstruction suggest that the early Holocene forest declines resulted from recurrent dry atmospheric conditions which were associated, in two cases (10.1 and 9.3 cal ka BP), with atmospheric cooling. Several studies have detected impacts of early Holocene abrupt climate events in the Iberian Peninsula, including lake aridification phases in central and Southern Spain (Vegas et al., 2009; Carrión, 2002), changes in fire regime and archaeological settlement patterns in the Ebro basin (González-Sampériz et al., 2009; Davis and Stevenson, 2007), and changes in oceanic moisture signals in a northern Spanish speleothem record (Domínguez-Villar et al., 2009). The findings of this study suggest that these diverse phenomena were related to a series of recurrent (dry) atmospheric climatic anomalies which can be furthermore associated with meltwater pulse perturbation of the North Atlantic climate as discussed in Sect. 5.2.

The forest decline centred on 10.1 cal ka BP coincides with cooling in the NGRIP record towards $9.95 \mathrm{ka}$, although this anomaly is not consistent across different Greenland records (Rasmussen et al., 2007). Cooling at this time is associated with a prominent SST cooling event in the eastern Norwegian Sea (Berner et al., 2010) which may be linked to meltwater discharge associated with the draining of the Baltic ice lake at $\sim 10.3 \mathrm{ka}$ and cooling during the Norwegian 'Erdalen' glacier advance (Nesje et al., 2004), or alternatively to contemporaneous outburst floods from glacial Lake Agassiz (Teller and Leverington, 2004). Forest minima centred at 9.2 and 8.4 cal $\mathrm{ka} \mathrm{BP}$ are in phase, and within age-model uncertainties, contemporaneous with highlatitude cooling events at 9.3 and $8.2 \mathrm{ka}$ detected in $\delta^{18} \mathrm{O}$ and accumulation signals in multiple Greenland ice cores (Rasmussen et al., 2007). These high-latitude coolings are likely to have been provoked by THC weakening related to meltwater discharges from glacial lakes Agassiz and Ojibway (Teller et al., 2002; Barber et al., 1999) or possibly with changes in overflow patterns from the Lake Superior basin (Breckenridge and Johnson, 2009), and are associated with climatic anomalies across the Northern Hemisphere (Fleitman et al., 2008; Alley and Ágústsdóttir, 2005). Finally, the forest 


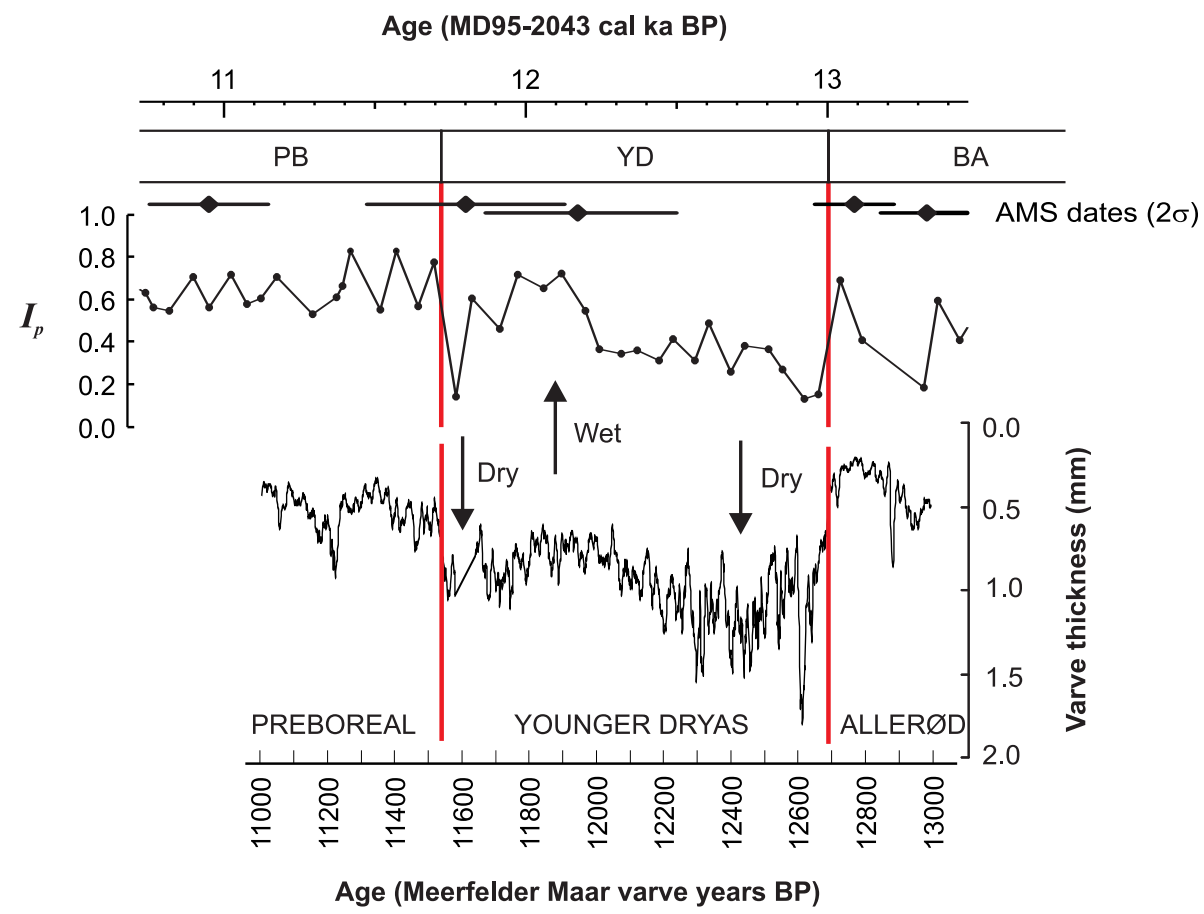

Fig. 6. Comparison of the MD95-2043 pollen-based precipitation index $\left(I_{p}\right)$ and Meerfelder Maar varve thickness record (Brauer et al., 1999) for the Younger Dryas interval. Note: the records are plotted on independent timescales and have been aligned visually with respect to the onset and end of the YD (red bars). Similarities in the records suggest parallel hydrological changes between Northern Europe and the Western Mediterranean, with dry conditions (lower $I_{p}$ values) in MD95-2043 associated with increased varve thicknesses and sedimentological indications (Brauer et al., 1999) of dry conditions at Meerfelder Maar.

decline detected during the final stages of the last deglaciation, with a minimum centred at $7.4 \mathrm{cal}$ ka BP coincides with meltwater outbursts from the Ungava and Labrador Lakes (Jansson and Kleman, 2004), and may reflect a late deglacial meltwater perturbation of the THC and North Atlantic climate.

Within dating uncertainties, Western Mediterranean forest declines coincide exactly with climatic anomalies at 8.2, 9.1 and $10.0 \mathrm{cal}$ ka detected in speleothem $\delta^{18} \mathrm{O}$ records from Katerloch Cave (southeastern Alps) (Boch et al., 2009), highlighting the wide regional impact and apparent synchrony of these climatic anomalies over southern and central Europe. The $\delta^{18} \mathrm{O}$ anomalies at Katerloch are interpreted to reflect cooling of up to $3{ }^{\circ} \mathrm{C}$, however the authors note that the $\delta^{18} \mathrm{O}$ anomalies could also result from short-lived reductions in the abundance of Mediterranean-derived moisture at the site (Boch et al., 2009). This latter interpretation is consistent with the evidence presented here for dry conditions during these events in the Western Mediterranean. The sequence of early Holocene forest declines at 10.1, 9.3, 8.2 and $7.4 \mathrm{cal} \mathrm{ka} \mathrm{BP}$ also corresponds closely to peaks in North Atlantic indicators of ice-rafting (hematite stained grains; Bond et al., 1997), suggesting a consistent signature of drier conditions in the Western Mediterranean during early Holocene N. Atlantic cooling events. A close match between intervals of
Western Mediterranean forest declines and intervals of midEuropean high lake-level intervals (Magny et al., 2007a), highlights a continued opposition of precipitation trends between the two geographic sectors.

\subsection{Regional patterns and a proposed atmospheric mechanism}

The MD95-2043 forest record indicates that the climate of the deglaciation period in the Western Mediterranean was characterised by pervasive variability at multi-centennial timescales and evident sensitivity to perturbation of the $\mathrm{N}$. Atlantic climate related to the state of meridional overturning and meltwater impacts. Comparison with mid-European lake-level records (Magny et al., 2007a; Magny, 2001) reveals a consistent opposition of hydrological trends, with dry conditions in the Western Mediterranean associated with mid-European high-lake levels during high-latitude and $\mathrm{N}$. Atlantic cooling events (GI-1d, GI-1b, YD (early and late phases), and events at $11.4,10.1,9.3,8.2$ and $7.4 \mathrm{ka}$ ). These findings extend the pattern proposed for the $8.2 \mathrm{ka}$ and PB Oscillation (11.4 ka event) (Magny et al., 2007a; 2003), and suggest a recurrent hydrological opposition between the Western Mediterranean and central-Western Europe during deglacial cooling events. As previously proposed for the $8.2 \mathrm{ka}$ and PB Oscillation (Magny et al., 2007a; 2003), and 
further supported by the comparison presented above with data from Meerfelder Maar for the YD, this opposition may be part of a recurrent N-S tripartite (dry-wet-dry) hydrological pattern over Western Europe.

It is interesting also to note that major Holocene highstands detected in the Lake Accesa record (Tuscany, Northern central Italy) at 11.5, 11.1, 10.2, 9.4, 8.2 and 7.3 cal ka BP (Magny et al., 2007b) correspond to dry intervals in the Alboran borderlands. In this respect, as Magny et al. (2007b) indicate, the record of Lake Accesa highstands conforms to the central-Western European pattern. Our findings therefore indicate not only an opposed hydrological pattern between the Western Mediterranean and central Europe, but also between the Western Mediterranean and Northern central Italy, highlighting important spatial variability in climatic patterns across the western and central sectors of the Mediterranean basin. In this case, the Holocene hydrological opposition with Lake Accesa is reminiscent of the frequent presentday occurrence during winter months of a marked sea-level pressure and precipitation gradient with centres of action in the Azores-Cádiz Gulf area and Northern Italy-AdriaticCentral Europe, the so-called Western Mediterranean Oscillation (WeMO) (Martín-Vide and López-Bustins, 2006). However, past variability in summer precipitation and evaporative balance may also be of significance for the Lake Accesa Holocene highstands.

The detection of (a) negative precipitation shifts in the study region during high-latitude cooling events and (b) the opposite precipitation pattern between the study region and central-Western Europe suggests important variability in the dynamics (intensity and position) of the westerly atmospheric flow. One possible atmospheric mechanism which may partly underline these observations relates to the prevalence of blocking episodes - an atmospheric situation of predominantly meridional flow with strong slow-moving or stationary anticyclones over the European mid-latitudes (Barry and Chorley, 1998). Blocking episodes are characterised by a branching of the jet stream, promoting significant increases in cyclonic activity and wetter than normal conditions over the Western Mediterranean basin and eastern Greenland (Trigo et al., 2004a). The contrasting (nonblocking) situation of strong zonal flow is characterised by significant, opposite patterns, i.e. frequent cyclone penetration into Northern and central Europe and drier than normal conditions in the Western Mediterranean basin and eastern Greenland (Trigo et al., 2004a). As individual blocking events can persist for weeks, a small number of blocking episodes can influence the climate characteristics of an entire season (Stein, 2000).

AGCM model simulations of the YD climate have shown that winter cooling and sea-ice formation in the North Atlantic region promotes a stable, strong westerly flow, dramatically reducing the occurrence of blocking highs and promoting the extension of cyclonic activity far into the Eurasian continent (Renssen et al., 1996). In the model, an enhanced westerly jet stream is promoted by the increased surface temperature gradient over the North Atlantic that results from perturbation of the THC and the development of sea-ice cover. Extending these findings to other deglacial cooling events associated with meltwater pulses into the North Atlantic and Arctic Oceans, the following scenario is proposed:

- During deglacial cooling events, THC weakening and sea-ice build-up at high-latitudes of the N. Atlantic (as simulated in Renssen et al., 2007; Wiersma and Renssen, 2006) increased the N. Atlantic surface temperature gradient, leading to jet stream intensification, the extension of cyclonic activity into the European mainland and drier conditions in the Western Mediterranean (prevalence of non-blocking situation).

- During warm intervals, weak meltwater perturbation, THC strengthening, reduced sea-ice extent and a reduced temperature gradient contributed to a weaker zonal flow permitting an increased frequency of blocking situations leading to enhanced cyclonic activity and precipitation over the Western Mediterranean and dry conditions in Western-central Europe (frequent blocking episodes).

The average precipitation anomaly associated with the Lateglacial and early Holocene forest decline events is estimated at $\sim 65 \mathrm{~mm} / \mathrm{yr}$. For winter seasons over the period 1958-1997, the difference between blocking and nonblocking episodes accounts for a difference in precipitation of $\sim 1 \mathrm{~mm}$ /day (Trigo et al., 2004a). As individual blocking episodes typically last between 5 and 30 days (Trigo et al., 2004a), a shift between winters with frequent, multiple blocking episodes and winters with a prevalent non-blocking situation could therefore account for precipitation anomalies on the order of those estimated on the basis of the MAT reconstructions.

Variability in the frequency of blocking episodes represents one example of a present day synoptic phenomenon related to changing intensity of the westerly zonal flow for which shifts between a prevailing positive or negative situation over longer timescales could explain geographic variability in past hydrological patterns over Europe. Of course, given that the zonal atmospheric flow over Western Europe constitutes at present one of the most variable and dynamic centres of atmospheric action in the Northern Hemisphere (Ding and Wang, 2005), relating past hydrological changes to a prevalence of specific synoptic configurations is extremely challenging, not least because they occurred in the context of Atlantic THC and sea-surface temperature perturbation for which historical analogues are not available.

It is interesting to note that the North Atlantic Oscillation (NAO), which represents the most important current mode of winter climate variability in the North Atlantic region (Hurrell, 1995) and which has been proposed as a mechanism to explain Iberian Peninsula moisture variability during the 
last glacial period (e.g. Naughton et al., 2009; Moreno et al., 2002), may not necessarily be a good candidate for explaining the deglacial hydrological opposition. While the NAO certainly accounts for a large part of precipitation variability in the study region, the NAO does not strongly influence precipitation variability in central Europe (Trigo et al., 2004b). Furthermore, precipitation variability related to the NAO is most significant (and opposed in sign) across two latitudinal bands, one southerly (Iberian Peninsula and the Mediterranean) and one northerly (British Isles, Scandinavia and the Baltic) (Trigo et al., 2004b). In contrast, blocking patterns can account for three latitudinal bands of opposite anomaly signs, with significant and positive (negative) anomalies in the Western Mediterranean and Northern Europe, and negative (positive) anomalies over central Europe. Further comparison of high-resolution palaeoclimate records from key geographic sectors is certainly necessary to refute or confirm the implication of specific atmospheric patterns such as the NAO in past hydrological patterns. However, we suggest that the blocking phenomenon as a mechanism for transmission of a spatially variable climate signal during abrupt deglacial events should certainly be tested against new palaeoclimate data and modeling studies.

\subsection{Chronology of Lateglacial events and possible implications for marine reservoir ages}

Abrupt climate changes of the last deglaciation were accompanied by large and geographically variable shifts in the radiocarbon enrichment of surface waters due to changes in oceanic circulation patterns (Bondevik et al., 2006; Robinson et al., 2005; Waelbroeck et al., 2001; Austin et al., 1995; Bard et al., 1994). These changes have important consequences for radiocarbon chronologies based on the dating of marine organisms (Björck et al, 2003). It is known that reservoir ages in the Mediterranean were enhanced during $\mathrm{H} 1$ by up to 400 years (Siani et al., 2001), and decreased towards the onset of the Holocene; however, few data are currently available to refine this scenario. The detection of abrupt climate shifts in the MD95-2043 TMF record which can be confidently correlated with high-latitude climate changes provides an opportunity to examine explicitly offsets between the radiocarbon and ice-core chronologies which may relate to changes in marine reservoir effect.

In Fig. 7, MD95-2043 calibrated radiocarbon ages are compared with ages on the GICC05 timescale (Rasmussen et al., 2006) for five major climatic transitions which can be identified by abrupt changes in the TMF record (onsets of the Bölling (GI-1), the Older Dryas (GI-1d), the Intra-Allerød Cold Period (GI-1b), the YD (GS-1) and the Holocene). The comparison shows that dates for the five events from the two cores may be identical when uncertainties in both the radiocarbon and ice-core timescales are taken into account. However, if differences between the two sets of dates resulted simply from methodological uncertainties inherent in the construction of the timescales, we would not anticipate a consistent pattern in the offsets between the dates. In fact, a consistent pattern of positive offsets is observed, reflecting the older age estimates on the radiocarbon than GICC05 timescale. It seems unlikely that the offsets (apparent leads) observed at these transitions in core MD95-2043 reflect real leads in environmental responses. Atmospheric climate changes are anticipated to have been virtually synchronous (on the order of 1-3 years) between Greenland and the Western Mediterranean due to the abrupt reorganisation of the mid-latitude atmospheric circulation occurring at climate event transitions (Steffensen et al., 2008), and slight lags (on the order of decades or less) might be expected related to resilience in ecosystem changes. The consistent positive offset could, however, be explained by an enhancement of the marine reservoir effect in the Western Mediterranean Sea during the Lateglacial period, with surface waters approximately 200 years older than the present day global mean age of $\sim 400$ years. The offsets suggest reservoir ages close to the calculated surface water ages given by the dating of marine organisms within tephra-layers in southern Adriatic marine sediments (Siani et al. (2001), Fig. 7), supporting this evidence for reduction of reservoir ages from $\mathrm{H} 1$ into the BA. Moreover, our findings also suggest a renewed enhancement of reservoir ages during the Allerød, with a larger offset than at either the onset of the Older Dryas (GI-1d) or the Holocene. This pattern is consistent with trends detected in a recent synthesis of northern North Atlantic surface water reservoir ages (Cao et al., 2007). This finding is reasonable, as no major change in the Mediterranean circulation pattern occurred and the renewal period of the Mediterranean is 100 years (Cacho et al., 2001; Siani et al., 2001).

Ideally, the hypothesis that reservoir ages in the Alboran Sea were enhanced during the Lateglacial could be tested explicitly by paired AMS dating of terrestrial pollen residues and marine foraminifera from known depths in the MD952043 core. Unfortunately, the low pollen concentration of $<10^{4}$ grains per $\mathrm{cm}^{3}$ (Fletcher and Sanchez Goñi, 2008) and the admixture of pollen with sporopollenin-based marine organisms such as dinoflagellates means that this task is not practically feasible. Nevertheless, the offsets observed in comparing the pollen and ice-core records may indicate similar Lateglacial trends in reservoir ages between the W. Mediterranean and North Atlantic, and provide a tentative scenario against which to compare future data on temporal and spatial variability in reservoir ages in the Mediterranean.

\subsection{Limitations}

Our findings demonstrate the sensitivity of the Mediterranean forest pollen signal to sub-millennial-scale climate variability and abrupt changes of the last deglaciation period. This sensitive register of climate change may relate to the integration of a vegetation signal from a very large regional source area, "averaging out" local patterns related to 


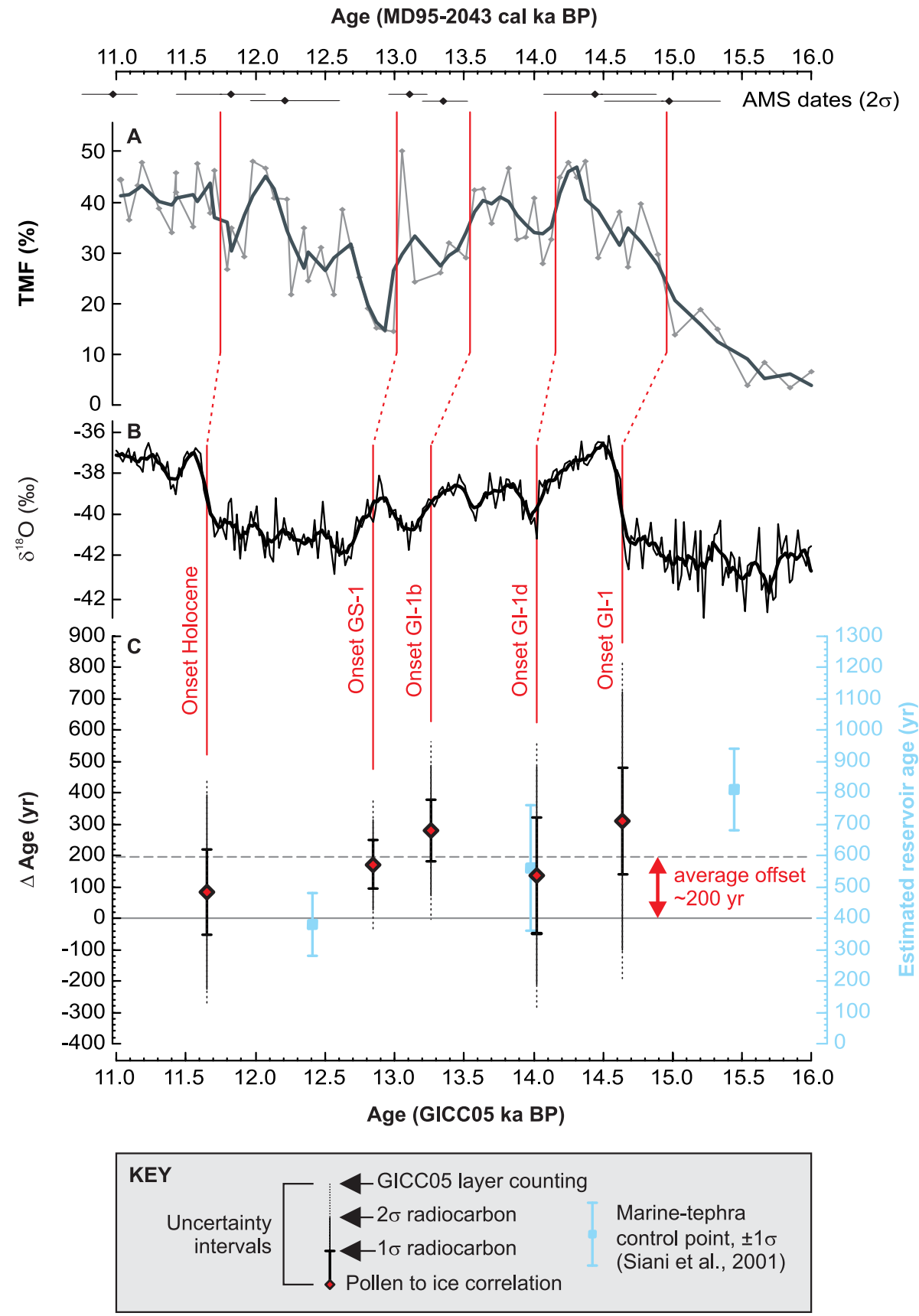

Fig. 7. Comparison of MD95-2043 radiocarbon and ice-core (GICC05) age estimates for five Lateglacial climatic transitions, showing: (A) Temperate Mediterranean forest (TMF) pollen curve from core MD95-2043 (raw values and 3-point moving average) plotted on the MD952043 calibrated radiocarbon timescale; (B) NGRIP $\delta^{18} \mathrm{O}$ values on the GICC05 timescale with 100-yr moving average (NGRIP members, 2004; Rasmussen et al., 2006); (C) Difference between calibrated radiocarbon age and GICC05 ages ( $y$-axis) plotted against the GICC05 timescale $(x$-axis). Positive values indicate older ages on the MD95-2043 radiocarbon timescale. Vertical error bars show uncertainty estimates in the radiocarbon age model, and ice-layer counting in the GICC05 timescale as published in Rasmussen et al. (2006). Surface water age estimates for the Adriatic from Siani et al. (2001). 
the heterogeneous landscapes and micro-climates of the surrounding regions. However, while the marine pollen record provides clear indications of rapid climate variability and suggests that precipitation changes were central to this variability, it cannot elucidate how climate impacts may have varied between different environmental settings (e.g. highlands, lowlands, wetlands), nor how vegetation changes were effected in terms of range and/or altitudinal shifts. These tasks need to be elaborated through the future study of terrestrial sequences with strong chronological control at highresolution.

Also, modern studies indicate a dominance of fluvial transport to the MD95-2043 core location in the Alboran Sea (Fabrés et al. 2001), and the good long-term correlation between the record of vegetation changes in MD95-2043 and at the southern Iberian site of Padul (shown in Fletcher and Sanchez Goñi, 2008) suggests a certain stability of pollen transport from the Iberian Peninsula over time. Nevertheless, given the difficulty of precise definition of the pollen source area for a marine pollen record, it cannot be excluded that changes in pollen source conditioned by concomitant effects of climatic changes (e.g. shifts in prevailing winds) may contribute to variability in the pollen signal. In the case of the Alboran Sea, further investigation of clay mineralogy for the identification of particulate transport from North African sources (Bout-Roumazeilles et al., 2007) could help constrain knowledge of past shifts in wind direction during multi-centennial-scale events.

\section{Conclusions}

The main findings of this study are:

- Changes in Western Mediterranean forest development (reflected in TMF values in the MD95-2043 pollen record) and shifts in vegetation composition (reflected in two novel pollen-based climatic indices, $I_{t}$ and $I_{p}$ ) indicate pervasive variability in atmospheric conditions during the deglaciation period $(20-6$ cal ka BP). In addition to major climatic shifts at the onsets of $\mathrm{H} 1$, the $\mathrm{BA}$ and the YD, multi-centennial-scale climate variability is expressed in forest decline intervals centred at $14.0,13.3,12.9,11.8,10.7,10.1,9.2,8.3$ and $7.4 \mathrm{cal} \mathrm{ka} \mathrm{BP.}$

- Forest declines related to drier atmospheric conditions occurred consistently during Lateglacial events of highlatitude cooling including GI-1d (Older Dryas), GI1b (Intra-Allerød Cold Period) and GS-1 (including multiple events), and during Holocene events associated with high-latitude cooling, meltwater pulses and N. Atlantic ice-rafting (events at 11.4, 10.1, 9.3, 8.2 and $7.4 \mathrm{cal} \mathrm{ka} \mathrm{BP).} P_{\text {ann }}$ reconstructions using the modern analogue technique suggest an average precipitation anomaly of $-65 \mathrm{~mm} / \mathrm{yr}$ during episodes of forest decline.

- Dry intervals in the Western Mediterranean region coincide with high lake-level (wet) intervals in Westerncentral Europe, confirming a previously identified pattern for the PB Oscillation and $8.2 \mathrm{ka}$ event (Magny et al., 2007a, 2003). The opposed hydrological pattern suggests recurrent shifts in the prevailing intensity and position of the westerly atmospheric flow over western and central Europe, possibly associated with changes in the prevalence of atmospheric blocking highs over European mid-latitudes.

- Although calibrated radiocarbon ages for abrupt forest changes correlated with the onsets of GI-1, GI-1d, GI$1 \mathrm{~b}, \mathrm{GS}-1$ and the Holocene may be synchronous with ages on the GICC05 timescale within methodological uncertainties, a consistent offset suggests that marine reservoir ages in the Alboran Sea may have been enhanced by $\sim 200$ years (surface water age $\sim 600$ years) during the Lateglacial.

Acknowledgements. This research was supported by ANR Blanc PIC. The authors gratefully recognise the work of the IMAGES program and the R/V Marion Dufresne, and thank the Muséum National d'Histoire Naturelle for contributions to the Bordeaux pollen reference collection. WJF gratefully acknowledges valuable discussions during a scientific visit to the CSIC Instituto Pirenaico de Ecología (Zaragoza, Spain). This paper is Université Bordeaux 1, UMR 5805 CNRS EPOC contribution no. 1778.

Edited by: C. Hatté

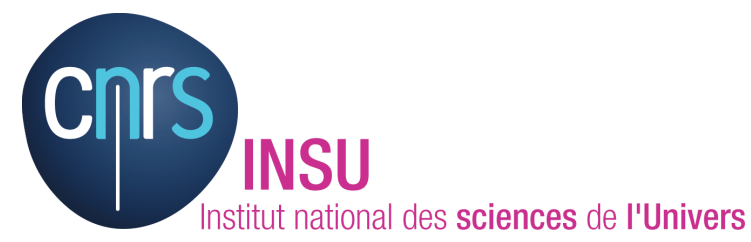

The publication of this article is financed by CNRS-INSU.

\section{References}

Alley, R. B. and Ágústsdóttir, A. M.: The $8 \mathrm{k}$ event: Cause and consequences of a major Holocene abrupt climate change, Quaternary Sci. Rev., 24, 1123-1149, 2005.

Arévalo Barroso, A.: Atlas Nacional de España, Sección II, Grupo 9, Climatología, Ministerio de Obras Públicas y Transportes, Dirección General del Instituto Geográfico Nacional, Madrid, 1992.

Austin, W. E. N., Bard, E., Hunt, J. B., Kroon, D., and Peacock, J. D.: The ${ }^{14} \mathrm{C}$ age of the Icelandic Vedde ash: Implications for 
Younger Dryas marine reservoir age corrections, Radiocarbon, 37, 53-62, 1995.

Barber, D. C., Dyke, A., Hillaire-Marcel, C., Jennings, A. E., Andrews, J. T., Kerwin, M. W., Bilodeau, G., McNeely, R., Southon, J., Morehead, M. D., and Gagnon, J.-M.: Forcing of the cold event of 8200 years ago by catastrophic drainage of Laurentide lakes, Nature, 400, 344-348, 1999.

Bard, E., Arnold, M., Mangerud, J., Paterne, M., Labeyrie, L., Duprat, J., Mélières, M.-A., Sønstergaard, E., and Duplessy, J. C.: The North Atlantic atmosphere-sea surface ${ }^{14} \mathrm{C}$ gradient during the Younger Dryas climatic event, Earth Planet Sc. Lett., 126, 275-287, 1994.

Bard, E., Arnold, M., Maurice, P., Duprat, J., Moyes., J., and Duplessy, J.-C.: Retreat velocity of the North Atlantic polar front during the last deglaciation determined by ${ }^{14} \mathrm{C}$ accelerator mass spectrometry, Nature, 328, 791-794, 1987.

Barry, R. G. and Chorley, R. J.: Atmosphere, weather and climate, Routledge, London, 7th edn., 409 pp., 1998.

Beaudouin, C., Suc, J.-P., Escarguel, G., Arnaud, M., and Charmasson, S.: The significance of pollen signal in present-day marine terrigenous sediments: The example of the Gulf of Lions (Western Mediterranean Sea), Geobios-Lyon, 40, 159-172, 2007.

Benabid, A.: Flore et ecosystems du Maroc, Editions Ibis Press, Paris, 360 pp., 2000.

Berner, K. S., Koç, N., and Godtliebsen, F.: High frequency climate variability of the Norwegian Atlantic Current during the early Holocene period and a possible connection to the Gleissberg cycle, The Holocene, 20, 245-255, 2010.

Björck, S., Kromer, B., Johnsen, S., Bennike, O., Hammarlund, D., Lemdahl, G., Possnert, G., Rasmussen, T. L., Wohlfarth, B., Hammer, C. U., and Spurk, M.: Synchronized terrestrialatmospheric deglacial records around the North Atlantic, Science, 274, 1155-1160, 1996.

Björck, J. and Wastegård, S.: Climate oscillations and tephrochronology in eastern middle Sweden during the last glacial-interglacial transition, J. Quaternary Sci., 14, 399-410, 1999.

Björck, S., Koç, N., and Skog, G.: Consistently large marine reservoir ages in the Norwegian Sea during the Last Deglaciation, Quaternary Sci. Rev., 22, 429-435, 2003.

Boch, R., Spötl, C., and Kramers, J.: High-resolution isotope records of early Holocene rapid climate change from two coeval stalagmites of Katerloch Cave, Austria, Quaternary Sci. Rev., 28, 2527-2538, 2009.

Bohncke, S. J. P. and Hoek, W. Z.: Multiple Oscillations during the Preboreal as recorded in a calcareous gyttja, Kingbeekdal, The Netherlands, Quaternary Sci. Rev., 26, 1965-1974, 2007.

Bond., G., Showers, W., Cheseby, M., Lotti, R., Almasi, P., Menocla, P., Priore, P., Cullen, H., Hajdas, I. and Bonani, G.: A pervasive millenial-scale cycle in North Atlantic Holocene and glacial climates, Science, 278, 1257-1266, 1997.

Bondevik, S., Mangerud, J., Birks, H. H., Gulliksen, S., and Reimer, P. J.: Changes in North Atlantic radiocarbon reservoir ages during the Allerød and Younger Dryas, Science, 312, 1514-1517, 2006.

Bordon, A., Peyron, O., Lézine, A.-M., Brewer, S., and Fouache, E.: Pollen-inferred late-glacial and Holocene climate in southern Balkans (lake Maliq), Quatern. Int., 200, 19-30, 2009.

Bout-Roumazeilles, V., Combourieu Nebout, N., Peyron, O., Cor- tijo, E., Landais, A., and Masson-Delmotte, V.: Connection between South Mediterranean climate and North African atmospheric circulation during the last $50000 \mathrm{yr}$ BP North Atlantic cold events, Quaternary Sci. Rev., 26, 3197-3215, 2007.

Brauer, A., Endres, C., Günter, C., Litt, T., Stebich, M., and Negendank, J. F. W.: High resolution sediment and vegetation responses to Younger Dryas climate change in varved lake sediments from Meerfelder Maar, Germany, Data archived at the World Data Center for Paleoclimatology, Boulder, Colorado, USA, Quaternary Sci. Rev., 18, 321-329, 1999.

Breckenridge, A. and Johnson, T. C.: Paleohydrology of the upper Laurentian great lakes from the late glacial to early Holocene, Quaternary Res., 71, 397-408, 2009.

Cacho, I., Grimalt, J. O., Pelejero, C., Canals, M., Sierro, F. J., Flores, J. A., and Shackleton, N. J.: Dansgaard-Oeschger and Heinrich event imprints in Alboran Sea temperatures, Paleoceanography, 14, 698-705, 1999.

Cacho, I., Grimalt, J. O., Canals, M., Sbaffi, L., Shackleton, N., Schönfeld, J., and Zahn, R.: Variability of the Western Mediterranean Sea surface temperature during the last 25000 years and its connection with the Northern Hemisphere climatic changes, Paleoceanography, 16, 40-52, 2001.

Cacho, I., Shackleton, N., Elderfield, H., Sierro, F. J. and Grimalt, J. O.: Glacial rapid variability in deep-water temperature and $\delta 18 \mathrm{O}$ from the Western Mediterranean Sea, Quaternary Sci. Rev., 25, 3294-3311, 2006.

Cao, L., Fairbanks, R. G., Mortlock, R. A., and Risk, M. J.: Radiocarbon reservoir age of high latitude North Atlantic surface water during the last deglacial, Quaternary Sci. Rev., 26, 732742, 2007.

Carlson, A. E., Clark, P. U., Haley, B. A., Klinkhammer, G. P, Simmons, K., Brook, E. J., and Meissner, K. J.: Geochemical proxies of North American freshwater routing during the Younger Dryas cold event, P. Natl. Acad. Sci. USA, 104, 6556-6561, 2007.

Carrión, J. S.: Patterns and processes of Late Quaternary environmental change in a montane region of southwestern Europe, Quaternary Sci. Rev., 21, 2047-2066, 2002.

Clark, P. U., Marshall, S. J., Clarke, G. K. C., Hostetler, S. W., Licciardi, J. M., and Teller, J. T.: Freshwater Forcing of Abrupt Climate Change During the Last Glaciation, Science, 293, 283287, 2001.

Combourieu Nebout, N., Paterne, M., Turon, J.-L., and Siani, G.: A high-resolution record of the last deglaciation in the central Mediterranean Sea: Palaeovegetation and palaeohydrological evolution, Quaternary Sci. Rev., 17, 303-317, 1998.

Combourieu Nebout, N., Turon, J.-L., Zahn, R., Capotondi, L., Londeix, L., and Pahnke, K.: Enhanced aridity and atmospheric high-pressure stability over the Western Mediterranean during the North Atlantic cold events of the past 50 k.y., Geology, 30, 863-866, 2002.

Combourieu Nebout, N., Peyron, O., Dormoy, I., Desprat, S., Beaudouin, C., Kotthoff, U., and Marret, F.: Rapid climatic variability in the west Mediterranean during the last 25000 years from high resolution pollen data, Clim. Past, 5, 503-521, 2009, http://www.clim-past.net/5/503/2009/.

Dansgaard, W., Johnsen, S. J., Clausen, H. B., Dahl-Jensen, D., Gundestrup, N. S., Hammer, C. U., Hvidberg, C. S., Steffensen, J. P., Sveinbjörnsdottir, A. E., Jouzel, J., and Bond, G.: Evidence for general instability of past climate from a 250-kyr ice-core 
record, Nature, 364, 218-220, 1993.

Davis, B. A. S. and Stevenson, A. C.: The 8.2 ka event and EarlyMid Holocene forests, fires and flooding in the Central Ebro Desert, NE Spain, Quaternary Sci. Rev., 26, 1695-1712, 2007.

Desprat, S., Sánchez Goñi, M. F., Turon, J.-L., McManus, J. F., Loutre, M. F., Duprat, J., Malaizé, B., Peyron, O., and Peypouquet, J.-P.: Is vegetation responsible for glacial inception during periods of muted insolation changes?, Quaternary Sci. Rev., 24, 1361-1374, 2005.

Ding, Q., and Wang, B.: Circumglobal teleconnection in the Northern Hemisphere summer, J. Climate, 18, 3483-3505, 2005.

Domínguez-Villar, D., Fairchild, I. J., Baker, A., Wang, X., Edwards, R. L., and Cheng, H.: Oxygen isotope precipitation anomaly in the North Atlantic region during the 8.2 ka event, Geology, 37, 1095-1098, 2009.

Donnelly, J. P., Driscoll, N. W., Uchupi, E., Keigwin, L. D., Schwab, W. C., Thieler, E.R. and Swift, S.A.: Catastrophic meltwater discharge down the Hudson River valley: a potential trigger for the Intra-Allerød Cold Period, Geology, 33, 89-92, 2005.

Dormoy, I., Peyron, O., Combourieu Nebout, N., Goring, S., Kotthoff, U., Magny, M., and Pross, J.: Terrestrial climate variability and seasonality changes in the Mediterranean region between 15000 and 4000 years BP deduced from marine pollen records, Clim. Past, 5, 615-632, 2009, http://www.clim-past.net/5/615/2009/.

Drescher-Schneider, R., de Beaulieu, J.-L., Magny, M., WalterSimonnet, A .-V., Bossuet, G., Millet, L., Brugiapaglia, E. and Drescher, A.: Vegetation history, climate and human impact over the last 15000 years at Lago dell'Accesa (Tuscany, central Italy), Veg. Hist. Archaebot., 16, 279-299, 2007.

Dykoski, C. A., Edwards, R. L., Cheng, H., Yuan, D., Cai, Y., Zhang, M., Lin, Y., Qing, J., An, Z., and Revenaugh, J.: A highresolution, absolute-dated Holocene and deglacial Asian monsoon record from Dongge Cave, China, Earth Planet. Sci. Lett., 233, 71-86, 2005.

Fabrés, J., Calafat, A., Sanchez-Vidal, A., Canals, M., and Heussner, S.: Composition and spatial variability of particle fluxes in the Western Alboran Gyre, Mediterranean Sea, J. Marine Syst., 33-34, 431-456, 2001.

Fleitmann, D., Mudelsee, M., Burns, S. J., Bradley, R. S., Kramers, J., and Matter, A.: Evidence for a widespread climatic anomaly at around $9.2 \mathrm{ka}$ before present, Paleoceanography, 23, PA1102, 2008.

Flesche Kleiven, H., Kissel, C., Laj, C., Ninnemann, U. S ., Richter, T. O., and Cortijo, E.: Reduced North Atlantic Deep Water Coeval with the Glacial Lake Agassiz Freshwater Outburst, Science, 319, 62-64, 2008.

Fletcher, W. J. and Sanchez Goñi, M. F.: Orbital and sub-orbital scale climate impacts on the vegetation of the W. Mediterranean basin during the last 48000 years, Quaternary Res., 70, 451-464, 2008.

Genty, D., Blamart, D., Ghaleb, B., Plagnes, V., Causse, Ch., Bakalowicz, M., Zouari, K., Chkir, N. , Hellstrom, J., Wainer, $\mathrm{K}$., and Bourges, F.: Timing and dynamics of the last deglaciation from European and North African $\delta^{13} \mathrm{C}$ stalagmite profiles - comparison with Chinese and South Hemisphere stalagmites, Quaternary Sci. Rev., 25, 2118-2142, 2006.

González-Sampériz, P., Utrilla, P., Mazo, C., Valero-Garcés, B., Sopena, M. C., Morellón, M., Sebastián, M., Moreno, A., and
Martínez-Bea, M.: Patterns of human occupation during the early Holocene in the central Ebro basin (NE Spain) in response to the 8.2 ka climatic event, Quaternary Res., 71, 121-132, 2009.

Gouveia, C., Trigo, R. M., DaCamara, C. C., Libonati, R., and Pereira, J. M. C.: The North Atlantic Oscillation and European vegetation dynamics, Int. J. Climatol., 28, 2008.

Guiot, J.: Methodology of the last climatic cycle reconstruction from pollen data, Palaeogeogr. Palaeocl., 80, 49-69, 1990.

Grootes, P. M., Stuiver, M., White, J. W. C., Johnsen, S., and Jouzel, J.: Comparison of oxygen isotope records from the GISP2 and GRIP Greenland ice cores, Nature, 366, 552-554, 1993.

Hammarlund, D., Edwards, T. W. D., Björck, S., Buchardt., B., and Wohlfarth, B.: Climate and environment during the Younger Dryas (GS-1) as reflected by composite stable isotope records of lacustrine carbonates at Torreberga, southern Sweden, J. Quaternary Sci., 14, 17-28, 1999.

Heusser, L. E. and Balsam, W. L.: Pollen distribution in the northeast Pacific Ocean, Quaternary Res. 7, 45-62, 1977.

Hughen, K. A., Baillie, M. G. L., Bard, E., Bayliss, A., Beck, J. W., Bertrand, C., Blackwell, P. G., Buck, C. E., Burr, G., Cutler, K. B., Damon, P. E., Edwards, R. L., Fairbanks, R. G., Friedrich, M., Guilderson, T. P., Kromer, B., McCormac, F. G., Manning, S., Bronk Ramsey, C., Reimer, P. J., Reimer, R. W., Remmele, S., Southon, J. R., Stuiver, M., Talamo, S., Taylor, F. W., van der Plicht, J., and Weyhenmeyer, C. E.: Marine04 Marine Radiocarbon Age Calibration, 0-26 Cal Kyr BP, Radiocarbon, 46, 1059-1086, 2004.

Hurrell, J. W.: Decadal trends in the North Atlantic Oscillation: Regional temperatures and precipitation, Science, 269, 676-679, 1995.

Jansson, K. N. and Kleman, J.: Early Holocene glacial lake meltwater injections into the Labrador Sea and Ungava Bay, Paleoceanography, 19, PA1001, doi:10.1029/2003PA000943, 2004.

Jouzel, J., Stievenarda, M., Johnsen, S. J., Landais, A., MassonDelmotte, V., Sveinbjornsdottir, A., Vimeuxa, F., Grafenstein, U.V., and White, J. W. C.: The GRIP deuterium-excess record, Quaternary Sci. Rev., 26, 1-17, 2007.

Kotthoff, U., Pross, J., Müller, U., Peyron, O., Schiedml, G., Schulz H., and Bordon, A.: Climate dynamics in the borderlands of the Aegean Sea during formation of sapropel S1 deduced from a marine pollen record, Quaternary Sci. Rev., 27, 832-845, 2008.

Lehman, S. J. and Keigwin, L. D.: Sudden changes in North Atlantic circulation during the last deglaciation, Nature, 356, 757762, 1992.

Lionello, P., Malanotte-Rizzoli, P., Boscolo, R., Alpert, P., Artale, V., Li, L., Luterbacher, J., May, W., Trigo, R., Tsimplis, M., Ulbric, U., and Xoplaki, E.: The Mediterranean climate: an overview of the main characteristics and issues, in: Mediterranean Climate Variability, Developments in earth and Environmental Sciences, edited by: Lionello, P., Malanotte-Rizzoli, P., and Boscolo, R., 4, Elsevier, Amsterdam, 1-26, 2006.

Lotter, A. F., Eicher, U., Siegenthaler, U., and Birks, H. J. B.: Lateglacial climatic oscillations as recorded in Swiss lake sediments, J. Quaternary Sci., 7, 187-204, 1992.

Magny, M.: Palaeohydrological changes as reflected by lake-level fluctuations in the Swiss Plateau, the Jura Mountains and the northern French Pre-Alps during the Last Glacial-Holocene transition: a regional synthesis, Global Planet. Change 30, 85-101, 2001. 
Magny, M., Bégeot, C., Guiot, J., and Peyron, O.: Contrasting patterns of hydrological changes in Europe in response to Holocene climate cooling phases, Quaternary Sci. Rev., 22, 1589-1596, 2003.

Magny, M., Aalbersberg, G., Bégeot, C., Benoit-Ruffaldi, P., Bossuet, G., Disnar, J. R., Heiri, O., Laggoun-Defarge, F., Mazier, F., Millet, L., Peyron, O., Vannière, B., and WalterSimonnet, A.-V.: Environmental and climatic changes in the Jura mountains (eastern France) during the Lateglacial-Holocene transition: a multi-proxy record from Lake Lautrey, Quaternary Sci. Rev., 25, 414-445, 2006.

Magny, M., Vannière, B., de Beaulieu, J.-L., Bégeot, C., Heiri, O., Millet, L., Peyron, O., and Walter-Simonnet, A.-V.: EarlyHolocene climatic oscillations recorded by lake-level fluctuations in west-central Europe and in central Italy, Quaternary Sci. Rev., 26, 1951-1964, 2007a.

Magny, M., de Beaulieu, J.-L., Drescher-Schneider, R., Vannière, B., Walter-Simonnet, A.-V., Miras, Y., Millet, L., Bossuet, G., Peyron, O., Brugiapaglia, E., and Leroux, A.: Holocene climate changes in the central Mediterranean as recorded by lake-level fluctuations at Lake Accesa (Tuscany, Italy), Quaternary Sci. Rev., 26, 1736-1758, 2007b.

Magri, D.: Late Quaternary vegetation history at Lagaccione near Lago di Bolsena (central Italy), Rev. Palaeobot., Palyno., 106, 171-208, 1999.

Martín-Vide, J. and López-Bustins, J.-A.: The Western Mediterranean Oscillation and rainfall in the Iberian Peninsula, Int. J. Climatol., 26, 1455-1475, 2006.

McManus, J. F., Francois, R., Gherardi, J.-M., Keigwin, L. D., and Brown-Leger, S.: Collapse and rapid resumption of Atlantic meridional circulation linked to deglacial climate changes, Nature, 428, 834-837, 2004.

Moreno, A., Cacho, I., Canals, M., Prins, M. A., Sanchez-Goñi, M. F., Grimalt, J. O., and Weltje, G. J.: Saharan dust transport and high-latitude glacial climatic variability: The Alboran sea record, Quaternary Res., 58, 318-328, 2002.

Mudie, P. J., Rochon, A., and Aksu, A. E.: Pollen stratigraphy of Late Quaternary cores from Marmara Sea: land-sea correlation and paleoclimatic history, Mar. Geol., 190, 233-260, 2002.

Muñoz Sobrino, C., Ramil-Rego, P., and Gómez-Orellana, L.: Late Würm and early Holocene in the mountains of northwest Iberia: biostratigraphy, chronology and tree colonization, Veg. Hist. Archaeobot., 16, 223-240, 2007.

Naughton, F., Sánchez Goni, M. F., Desprat, S., Turon, J. L., Duprat, J., Malaizé, B., Joli, C., Cortijo, E., Drago, T., and Freitas, M. C.: Present-day and past (last 25000 years) marine pollen signal off western Iberia, Mar. Micropaleontol., 62, 91114, 2007.

Naughton, F., Sánchez Goñi, M. F., Kageyama, M., Bard, E., Duprat, J., Cortijo, E., Desprat, S., Malaizé, B., Joly, C., Rostek, F., and Turon, J. L.: Wet to dry climatic trend in north-western Iberia within Heinrich events, Earth Planet. Sc. Lett., 284, 329342, 2009.

Nesje, A., Dahl, S. O., and Bakke, J.: Were abrupt Lateglacial and early-Holocene climatic changes in northwest Europe linked to freshwater outbursts to the North Atlantic and Arctic Oceans?, The Holocene, 14, 299-310, 2004.

North Greenland Ice Core Project members: High-resolution record of Northern Hemisphere climate extending into the last inter- glacial period, Nature, 431, 147-151, 2004.

Peinado Lorca, M. and Rivas-Martinez, S.: La vegetación de España, Universidad de Alcala de Henares, Secretaria general, Servicio de publicaciones, 1987.

Peyron, O., Guiot, J., Cheddadi, R., Tarasov, P., Reille, M., de Beaulieu, J.-L., Bottema, S., and Andrieu, V.: Climatic Reconstruction in Europe for 18000 yr BP from Pollen Data, Quaternary Res., 49, 183-196, 1998.

Pérez-Obiol, R. and Julià, R.: Climatic change on the Iberian Peninsula recorded in a $30000-y r$ pollen record from Lake Bannyoles, Quaternary Res., 41, 91-98, 1994.

Pons, A. and Reille, M.: The Holocene and Upper Pleistocene pollen record from Padul (Granada, Spain): a new study, Palaeogeogr. Palaeocl., 66, 243-263, 1988.

Quezel, P.: Réflexions sur l'évolution de la flore et de la végétation au Maghreb méditerranéen, Ibis Press, Paris, 2002.

Rasmussen, S. O., Andersen, K. K., Svensson, A. M., Steffensen, J. P., Vinther, B. M., Clausen, H. B., Siggaard-Andersen, M.L., Johnsen, S. J., Larsen, L. B., Dahl-Jensen, D., Bigler, M., Röthlisberger, R., Fischer, H., Goto-Azuma, K., Hansson, M. E., and Ruth, U. : A new Greenland ice core chronology for the last glacial termination, J. Geophys. Res., 111, D06102, doi:10.1029/2005JD006079, 2006.

Rasmussen, S. O., Vinther, B. M., Clausen, H. B., and Andersen, K. K.: Early Holocene climate oscillations recorded in three Greenland ice cores, Quat. Sci. Rev., 26, 1907-1914, 2007.

Renssen, H., Lautenschlager, M., and Schuurmans, C. J. E.: The atmospheric winter circulation during the Younger Dryas stadial in the Atlantic/European sector, Clim. Dynam., 12, 813-824, 1996.

Renssen, H., Goosse, H., and Fichefet, T.: Simulation of Holocene cooling events in a coupled climate model, Quaternary Sci. Rev., 26, 2019-2029, 2007.

Robinson, L. F., Adkins, J. F., Keigwin, L. D., Southon, J., Fernandez, D. P., Wang, S.-L., and Scheirer, D. S.: Radiocarbon variability in the Western North Atlantic during the last deglaciation, Science, 310, 1469-1473, 2005.

Rohling, E. E. and Pälike, H.: Centennial-scale climate cooling with a sudden cold event around 8.200 years ago, Nature, 434, 975979, 2005.

Sánchez-Goñi, M. F., Cacho, I., Turon, J.-L., Guiot, J., Sierro, F. J., Peypouquet, J.-P., Grimalt, J. O., and Shackleton, N. J.: Synchroneity between marine and terrestrial responses to millennial scale climatic variability during the last glacial period in the Mediterranean region, Clim. Dynam., 19, 95-105, 2002.

Sánchez Goñi, M. F., Landais, A., Cacho, I., Duprat, J., and Rossignol, L.: Contrasting intrainterstadial climatic evolution between high and middle North Atlantic latitudes: A close-up of Greenland Interstadials 8 and 12, Geochem. Geophy. Geosy., 10, Q04U04, 2009.

Siani, G., Paterne, M., Michel, E., Sulpizio, R., Sbrana, A., Arnold, M., and Haddad, G.: Mediterranean sea surface radiocarbon reservoir age changes since the Last Glacial Maximum, Science, 294, 1917-1920, 2001.

Stein, O.: The variability of Atlantic-European blocking as derived from long SLP time series, Tellus, 52A, 225-236, 2000.

Steffensen, J. P., Andersen, K. K., Bigler, M., Clausen, H. B., DahlJensen, D., Fischer, H., Goto-Azuma, K., Hansson, M., Johnsen, S. J., Jouzel, J., Masson-Delmotte, V., Popp, T., Rasmussen, S. O., Röthlisberger, R., Ruth, U., Stauffer, B., Siggaard-Andersen, 
M.-L., Sveinbjörnsdóttir, A. E., Svensson, A., and White, J. W. C.: High resolution Greenland ice core data show abrupt climate change happens in few years, Science, 321, 680-684, 2008.

Stuiver, M. and Reimer, P. J.: Extended ${ }^{14} \mathrm{C}$ database and revised CALIB radiocarbon calibration program, Radiocarbon, 35, 215230, 1993.

Teller, J. T., Leverington, D. W., and Mann, J. D.: Freshwater outbursts to the oceans from glacial Lake Agassiz and their role in climate change during the last deglaciation, Quaternary Sci. Rev., 21, 879-887, 2002.

Teller, J. T. and Leverington, D. W.: Glacial Lake Agassiz: A 5000 year history of change and its relationship to the $\square 180$ record of Greenland, Geological Society of America Bulletin, 116, 729742, 2004.

Trigo, R. M., Trigo, I. F., DaCamara, C. C., and Osborn, T. J.: Climate impact of the European winter blocking episodes from the NCEP/NCAR Reanalyses, Clim. Dynam., 23, 17-28, 2004a.

Trigo, R. M., Pozo-Vázquez, D., Osborn, T. J., Castro-Diez, Y., Gámiz-Fortis, S., and Esteban-Parra, M.: North Atlantic Oscillation influence on precipitation, river flow and water resources in the Iberian Peninsula, Int. J. Climatol., 24, 925-944, 2004b.

van der Knaap, W. O. and van Leeuwen, J. F. N.: Late Glacial and early Holocene vegetation succession, altitudinal vegetation zonation, and climatic change in the Serra da Estrela, Portugal, Rev. Palaeobot. Palyno., 97, 239-28, 1997.
Vegas, J., Ruiz-Zapata, B., Ortiz, J. E., Galán, L., Torres, T., GarcíaCortés, A., Gil-García, M. J., Pérez-González, A., and GallardoMillán, J. L.: Identification of arid phases during the last 50 cal. ka BP from the Fuentillejo Maar-lacustrine record (Campo de Calatrava volcanic field, Spain), J. Quaternary Sci., in press, doi:10.1002/jqs.1262, 2009.

von Grafenstein, U., Erlenkeuser, H., Brauer, A., Jouzel, J., and Johnsen, S. J.: A mid-european decadal isotope-climate record from 15500 to 5000 Years B.P., Science, 284-1654-1657, 1999.

Waelbroeck, C., Duplessy, J.-C., Michel, E., Labeyrie, L., Paillard, D., and Duprat, J.: The timing of the last deglaciation in North Atlantic climate records, Nature, 412, 724-727, 2001.

Wang, Y. J., Cheng, H., Edwards, R. L., An, Z. S., Wu, J. Y., Shen, C.-C., and Dorale, J. A.: A high-resolution absolute-dated late Pleistocene monsoon record from Hulu Cave, China, Science, 294, 2345-2348, 2001.

Whittington, G., Fallick, A. E., and Edwards, K. J.: Stable oxygen isotope and pollen records from eastern Scotland and a consideration of Lateglacial and early Holocene climate change for Europe, J. Quaternary Sci., 11, 327-340, 1996.

Wiersma, A. P. and Renssen, H.: Model-data comparison for the 8.2 ka BP event: confirmation of a forcing mechanism by catastrophic drainage of Laurentide Lakes, Quaternary Sci. Rev., 25, 63-88, 2006. 